\title{
Distribution of Polychlorinated Biphenyls in the Housatonic River and Adjacent Aquifer, Massachusetts
}

\section{United States Geological Survey Water-Supply Paper 2266}

Prepared in cooperation with the Commonwealth of Massachusetts, Water Resources Commission, Department of

Environmental Quality Engineering, Division of Water Pollution Control, Technical Services Branch

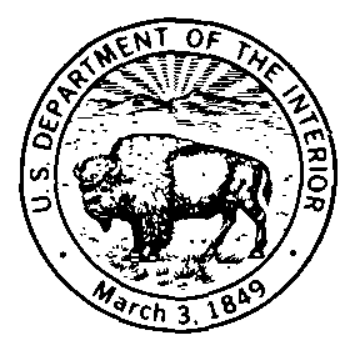




\section{Distribution of Polychlorinated Biphenyls in the Housatonic River and Adjacent Aquifer, Massachusetts}

BY FREDERICK B. GAY and MICHAEL H. FRIMPTER

Prepared in cooperation with the Commonwealth of Massachusetts, Water Resources Commission, Department of Environmental Quality Engineering, Division of Water Pollution Control, Technical Services Branch 


\title{
DEPARTMENT OF THE INTERIOR DONALD PAUL HODEL, Secretary
}

\author{
U.S. GEOLOGICAL SURVEY
}

Dallas L. Peck, Director

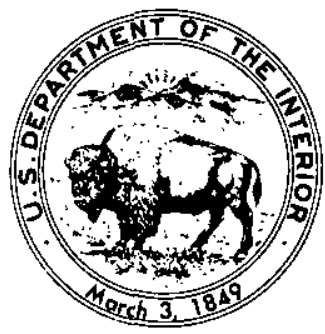

For sale by the Distribution Branch, U.S. Geological Survey, 604 South Pickett Street, Alexandria, VA 22304

\section{Library of Congress Cataloging-in-Publication Data}

Gay, Frederick B.

Distribution of polychlorinated biphenyls in the Housatonic River and adjacent aquifer, Massachusetts.

(U.S. Geological Survey ; Water-supply paper 2266)

Bibliography: p. 24

Supt. of Docs. no.: | 19.13:2266

1. Polychlorinated biphenyls-Environmental aspects-

Housatonic River Watershed (Mass. and Conn.) 2. Water,

Underground-Pollution-Housatonic River Watershed

(Mass. and Conn.) I. Frimpter, Michael H., 1934-

II. Massachusetts. Division of Water Poliution Control Technical Services Branch. IIt. Title. IV. Series:

Geological Survey water-supply paper ; 2266.

TD427.P65G39
600146 


\title{
CONTENTS
}

\author{
Abstract 1 \\ Introduction 1 \\ Purpose and scope 3 \\ Acknowledgments 3 \\ Geohydrologic setting 3
}

Chemistry of polychlorinated biphenyls 4

Distribution of polychlorinated biphenyls in the Housatonic River 6

Bottom sediments 6

River water 9

Hydrogeology of the Woods Pond test site 10

Description 10

Ground-water sampling network 12

Ground-water flow 18

Surface-water/ground-water interaction $\mathbf{1 8}$

Effect of polychlorinated biphenyls in river sediments on

adjacent ground water 23

Summary and conclusions 24

References 24

Metric conversion factors 26

FIGURES

1. Map showing location of Housatonic River drainage basin 2

2-4. Diagrams showing:

2. Idealized pattern of ground-water flow under natural conditions 4

3. Idealized pattern of ground-water flow under pumping conditions 5

4. Typical chemical structure of a chlorobiphenyl molecule 5

5. Map showing concentration of PCB's sorbed to bottom sediments along the Southwest, West, and East Branch Housatonic Rivers and the Housatonic River in Massachusetts 7

6-8. Graphs showing:

6. Maximum PCB concentration in bottom sediments and altitude above sea level of the water surface along the East Branch Housatonic River and the Housatonic River in Massachusetts 8

7. Annual peak-streamflow frequency curve for the Housatonic River near Great Barrington gaging station for water years 1914-82 11

8. Flow-duration curve for the Housatonic River near Great Barrington gaging station for water years 1914-81 12

9-12. Maps showing:

9. Concentration of PCB's sorbed to bottom sediments in Woods Pond and immediately upstream and downstream 13

10. Locations of industrial water-supply wells and areal extent of the aquifer 14

11. Location of the observation-well network used to sample for PCB's in the aquifer adjacent to Woods Pond 15

12. Location of wells, altitude of water table, and direction of ground-water flow in the aquifer adjacent to Woods Pond 16 
13-17. Diagrams showing:

13. Locations of well screens and distribution of hydraulic head in the aquifer adjacent to Woods Pond 17

14. Distribution of water temperature in Woods Pond and adjacent aquifer 19

15. Distribution of dissolved oxygen in Woods Pond and adjacent aquifer 20

16. Distribution of total ammonia and nitrate ions in the aquifer adjacent to Woods Pond 21

17. Distribution of total iron and manganese in the aquifer adjacent to Woods Pond 22 


\section{Distribution of Polychlorinated Biphenyls in the Housatonic River and Adjacent Aquifer, Massachusetts}

\author{
By Frederick B. Gay and Michael H. Frimpter
}

\section{Abstract}

Polychlorinated biphenyls (PCB's) are sorbed to the fine-grained stream-bottom sediments along the Housatonic River from Pittsfield, Massachusetts, southward to the Massachusetts-Connecticut boundary. The highest PCB concentrations, up to 140,000 micrograms per kilogram, were found in samples of bottom material from a reach of the river between Pittsfield and Woods Pond Dam in Lee, Massachusetts. Sediments in Woods Pond have been estimated to contain about 11,000 pounds of PCB's. Approximately 490 pounds per year of PCB's have also been estimated to move past the Housatonic River gaging station at Great Barrington.

The distribution of hydraulic heads, water temperatures, and concentrations of dissolved oxygen, ammonia, nitrate, iron, and manganese in ground water shows that industrial water-supply wells in a sand and gravel aquifer adjacent to a stretch of the river called Woods Pond have been inducing ground-water recharge through the PCBcontaminated bottom sediments of the pond since late 1956. These data indicate that, at one location along the shore of the pond, the upper $\mathbf{4 0}$ feet of the aquifer contains water derived from induced infiltration. However, this induced recharge has not moved PCB's from the bottom sediments into a vertical section of the aquifer located 5 feet downgradient from the edge of Woods Pond. Samples taken at selected intervals in this section showed that no PCB's sorbed to the aquifer material or dissolved in the ground water within the detection limits of the chemical analyses.

\section{INTRODUCTION}

The Housatonic River forms in Pittsfield, Mass., where the Southwest, West, and East Branch Housatonic Rivers join. The river flows southward through Berkshire County in western Massachusetts for about 50 miles. The river crosses into Connecticut about 1 mile north of Canaan, Conn., then continues about 85 river miles southward through western Connecticut to Long Island Sound. The Housatonic River drains $504 \mathrm{mi}^{2}$ in western Massachusetts, $217 \mathrm{mi}^{2}$ in eastern New York, and $1,232 \mathrm{mi}^{2}$ in western Connecticut (fig. 1). For many years, large quantities of industrial and municipal wastes were disposed of in the river, degrading water quality and limiting the use of the river. Since the mid-1960's, water quality has improved through efforts to limit the discharge of untreated and poorly treated wastewater. Currently, river water is being used for (1) water supply through induced infiltration to wells for industries and municipalities, (2) generation of electricity, (3) disposal of treated industrial and municipal wastewater, (4) recreational fishing, particularly in Connecticut, (5) canoeing, and (6) nature studies.

From the early 1930's to March 1977, PCB's (polychlorinated biphenyls), particularly Aroclors 1254 and 1260, were used in the manufacture of electrical transformers at a General Electric Company facility in Pittsfield (Connecticut Academy of Science and Engineering, 1978). A CASE (Connecticut Academy of Science and Engineering) report in 1978 concluded that leakage from the Pittsfield facility was the largest known source of PCB's to the Housatonic River. During the 1970's, the General Electric Company instituted rigorous procedures to control the use and the leakage of PCB's to the environment after a large number of studies revealed that health problems, such as a skin rash called chloracne, were connected with exposure to PCB's. ${ }^{1}$ Recognition of the potential toxicity and environmental persistence of PCB's resulted, in 1977, in a nationwide prohibition on their manufacture, processing, distribution, and use in all but totally enclosed systems. The prohibition was mandated by the Toxic Substances Control Act of 1976, Public Law 94-469, to which the reader may refer for its other provisions.

In 1974-75 PCB's were detected in river sediments in Connecticut, and in 1976-77 PCB's were identified in bottom sediments in the large im-

'Further information on these health issues can be found in reports by Connecticut Academy of Science and Engineering (1978), Westin (1979), Environmental Criteria and Assessment Office (1980), and Miller (1983). 


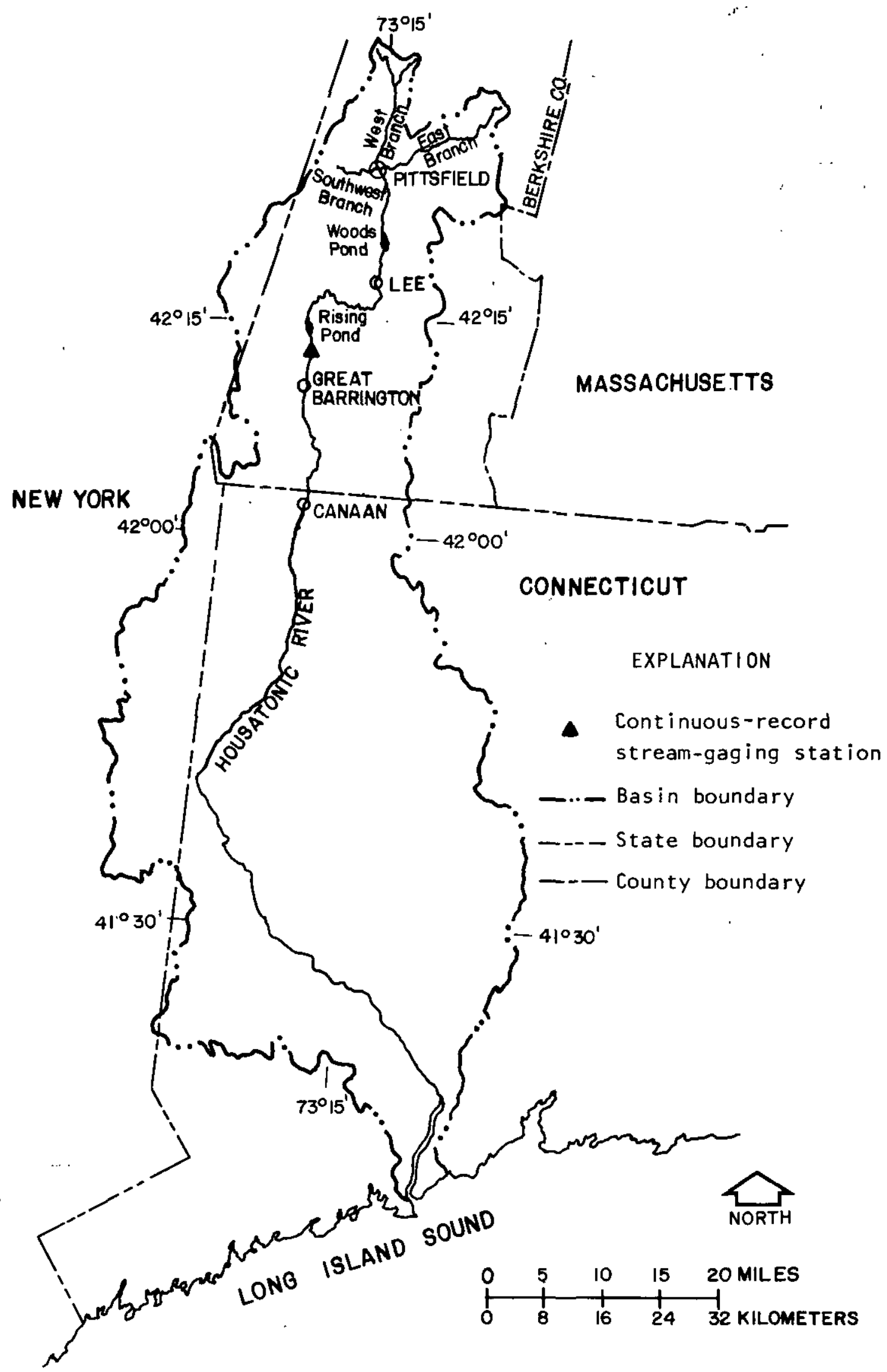

Figure 1. Location of Housatonic River drainage basin. 
pounded lakes along the river in Connecticut by the Survey (U.S. Geological Survey). These data are in the files of the Survey's Connecticut office. In 1977, PCB levels exceeding the limit of 5 parts per million set by the U.S. Food and Drug Administration were detected in fish caught in the river in Connecticut (Connecticut Academy of Science and Engineering, 1978). During the same period, samples of bottom sediments and fish collected from the Housatonic River in Massachusetts showed significantly higher concentrations of PCB's than were found in Connecticut (Massachusetts Department of Environmental Quality Engineering data files). Because of the occurrence of PCB's in the river sediments and the potential health problems they posed, concern developed about the potential contamination of municipal ground-water supplies adjacent to the river. As a result, development of new municipal-supply wells along the Housatonic River was not permitted by the Massachusetts Department of Environmental Quality Engineering until it could be demonstrated that PCB's in the river were not a threat to ground-water quality.

In early 1979 , the Survey, in cooperation with the Connecticut Department of Environmental Protection and the Connecticut Agricultural Experimental Station, began a detailed study of the bottom sediments along the river to determine the concentration of PCB's in the sediments and the rate of transport downstream. In late 1979, the Massachusetts Department of Environmental Quality Engineering, Division of Water Pollution Control, entered into a cooperative agreement with the Survey to study the movement of PCB's from the river through the ground to wells (the study reported here). Both of these studies began with a determination of the areal and vertical distribution of PCB's in the streambed sediments between Dalton, Mass., and the Massachusetts-Connecticut State line. All data on PCB's in stream-bottom sediments collected in both Massachusetts and Connecticut are given in Frink and others (1982).

\section{Purpose and Scope}

The purpose of this paper is to report the effects of the PCB's from the stream-bottom materials in the Housatonic River on an adjacent aquifer under conditions of induced infiltration. The study described was done at a well site adjacent to a ponded stretch of the river where PCB concentrations in the streambottom materials are high and cover a large area, and where industrial water-supply wells have induced stream-water infiltration for a number of years. The site is a sand and gravel aquifer adjacent to Woods Pond on the Housatonic River in Lee, Mass. The paper describes the chemistry of PCB's, the distribution of PCB's in bottom sediments and water in the Housatonic River and in Woods Pond, and the effects of PCB's in the Housatonic River on adjacent ground water.

\section{Acknowledgments}

The authors wish to acknowledge and thank the many individuals and organizations who kindly gave time and information to this study. Particular thanks is given to Richard Krueger, general manager of the P.J. Schweitzer Division, Kimberly-Clark Corporation, located in Lee, Mass., for granting permission to use the company's well field located on the south side of Woods Pond. Other individuals within Schweitzer Division who were very cooperative and helpful are John Cahalen, technical manager; John Hansen, assistant technical manager; and Joseph Rock. In addition, the following individuals provided important assistance: Everett Buffoni, superintendent, Lee Water Department; and Frank Macy, plant manager of the Lane Construction Corporation in Lee.

\section{Geohydrologic Setting}

The Housatonic River basin is underlain by metamorphic and sedimentary rocks. Quartzite, schist, and gneiss, which are resistant to erosion, form the uplands. Carbonate rocks such as limestone, dolomite, and marble, which are more easily eroded, generally underlie the major valleys. A thin mantle of unconsolidated glacial deposits covers the bedrock surface. These deposits are composed predominantly of till in the upland areas and stratified drift in the valleys. The stratified drift is composed of coarsegrained sediments that are well sorted, porous, and permeable. Where the saturated thickness of the stratified drift exceeds $25 \mathrm{ft}$, the drift forms an aquifer capable of sustaining municipal or industrial water supplies. A more complete description of the aquifers in the Housatonic River basin is given by Norvitch and others (1968).

The mean annual precipitation in the Housatonic River basin in Massachusetts is about 46 in.; in an average year about half of that water is returned to the atmosphere by evaporation and transpiration. Of the remaining half, about 50 percent flows through the basin's unconsolidated deposits and bedrock and discharges to the river and about 50 percent flows over the land surface to the river (Norvitch and others, 1968). 


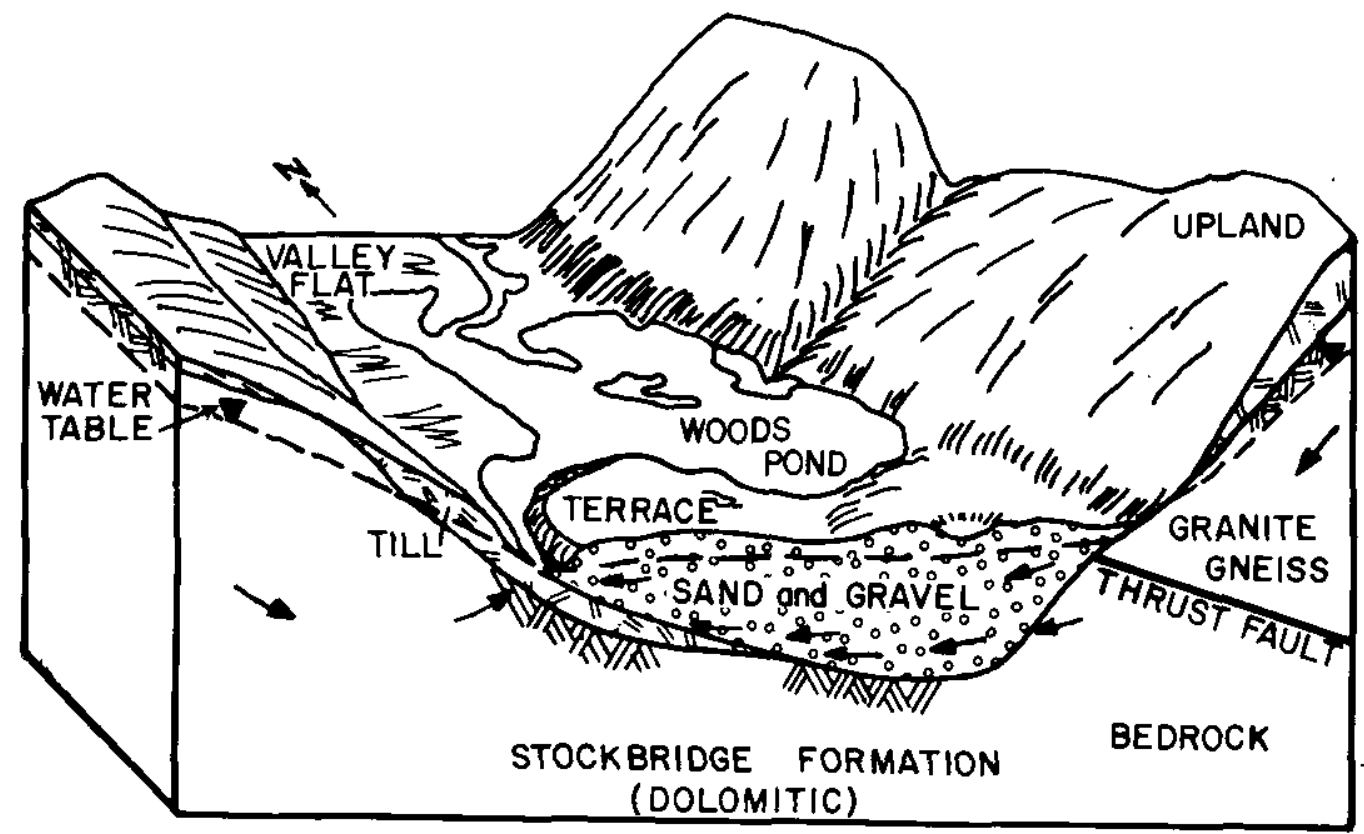

EXPLANAT ION

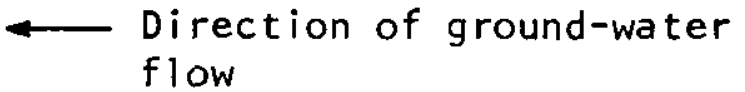

Figure 2. Idealized pattern of ground-water flow under natural conditions.

Water that enters the ground from precipitation flows through the bedrock, till, and stratified drift and discharges into streams and ponds, as shown in figure 2. Wells that are finished in and pump from the stratified drift can intercept this ground-water discharge. A heavily pumped well adjacent to a stream or pond will intercept ground-water discharge and may also induce stream water to infiltrate through the streambed and enter the aquifer, as shown in figure 3 .

\section{CHEMISTRY OF POLYCHLORINATED BIPHENYLS}

PCB is a generic name for a class of aromatic chlorinated organic compounds. PCB's are formed by first linking two benezene rings by covalent bonding between two carbon atoms to form a biphenyl molecule and then substituting chlorine atoms for one or more hydrogen atoms to form a chlorobiphenyl molecule, as shown in figure 4. PCB's were manufactured in this country by Monsanto Chemical Company and marketed under the trade name "Aroclor," followed by a four-digit number, such as Aroclor 1254. The first two digits, "12," indicate a polychlorinated biphenyl compound and the last two digits, "54," indicate the approximate percentage of chlorine, by weight, in that compound. One exception is Aroclor 1016, which is a PCB compound containing 41 percent chlorine.

The more chlorine atoms in the chlorobiphenyl molecule, the more resistant the isomer to biodegradation. Most bacteria are incapable of degrading PCB compounds because their enzymes cannot shear the chlorine-carbon bond. However, there have been a few bacteria isolated from the environment that can degrade PCB's (Griffin and Chian, 1980).

PCB's are slightly soluble in water. In general, researchers have found an inverse correlation between solubility of PCB's in water and the number of chlorine atoms in the isomer. However, there is a wide range in published values of the solubility of the 


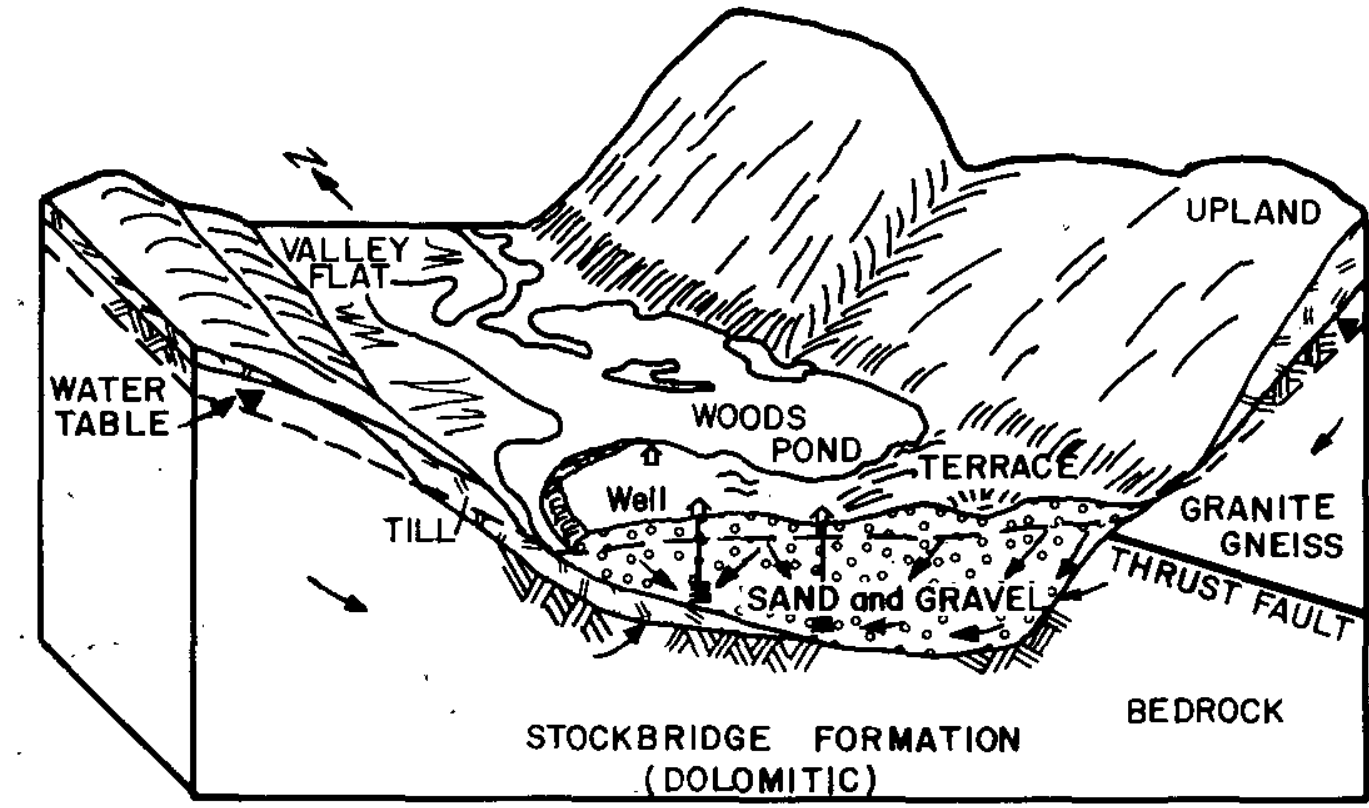

\section{EXPLANATION}

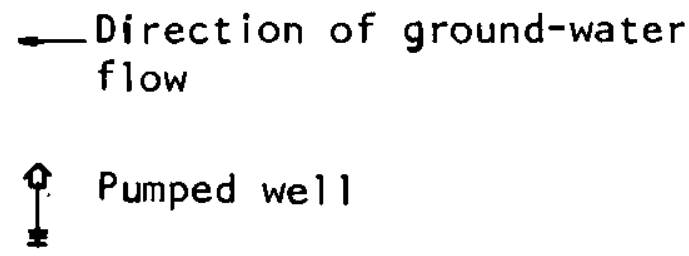

Figure 3. Idealized pattern of ground-water flow under pumping conditions.

same Aroclor. Haque and others (1974) determined the solubility of Aroclor 1254 in water at room temperature to be approximately $56 \mu \mathrm{g} / \mathrm{L}$ (micrograms<smiles>Clc1ccc(-c2c(Cl)ccc(Cl)c2Cl)c(Cl)c1Cl</smiles>

Figure 4. Typical chemical structure of a chlorobiphenyl molecule. per liter), whereas Schoor (1975) determined it to be less than $0.1 \mu \mathrm{g} / \mathrm{L}$. The solubility of Aroclor 1260 in water was found to be $2.7 \mu \mathrm{g} / \mathrm{L}$ at $25^{\circ} \mathrm{C}$ by Mackay and Wolkoff (1973) and approximately $25 \mu \mathrm{g} / \mathrm{L}$ at $20^{\circ} \mathrm{C}$ by Nisbet and Sarofim (1972).

PCB's have a strong affinity for soils, sediments, and particulate matter present in the environment (Haque and others, 1974). The degree of sorbtion of PCB's by the solid seems to be positively correlated with the total organic carbon content and with the ratio of surface area to weight, with total organic carbon being the more important. In addition, Haque and Schmedding (1976) noted that sorbtion by the solid increases as the number of chlorine atoms attached to the PCB molecule increases.

PCB's have been shown to be volatile in water (Uhlken and others, 1973) but markedly less volatile 
in the presence of sediments (Oloffs and others, 1973). In addition, it seems that as the chlorination of the PCB molecule increases, volatility decreases.

\section{DISTRIBUTION OF \\ POLYCHLORINATED BIPHENYLS IN THE HOUSATONIC RIVER}

\section{Bottom Sediments}

Analyses for PCB's in bottom sediments from the Southwest and West Branch Housatonic Rivers and the East Branch Housatonic River upstream of the General Electric Company facility in Pittsfield (fig. 5) showed a range of concentration, from 30 to $47 \mu \mathrm{g} / \mathrm{kg}$ (micrograms per kilogram of bottom material), and a mean of $40 \mu \mathrm{g} / \mathrm{kg}$, or about 40 parts per billion. These values are considered background concentration levels of PCB's in river sediments in this area. The probable sources of these PCB's are volatilization during incineration of solid wastes at temperatures too low to alter the chemical compostion of PCB's (Crump-Wiesner and others, 1973) and volatilization of PCB compounds from soil and water, both followed by transport and deposition from the atmosphere (Nelson and others, 1972). These volatile PCB's (aerosols) are transported by the wind, but many are deposited from the atmosphere onto land and water surfaces near the source.

When PCB's are discharged into a river, they are readily sorbed by the fine-grained organic or inorganic particles that are suspended in the water. These particles are held in suspension by the velocity of the river water and are transported downstream. In reaches along the stream where the stream velocity decreases, such as behind a dam, these particles settle and form a layer of PCB-laden bottom sediments on the stream bottom or the adjacent flood plain. During floods, the stream-water velocity may be sufficient to resuspend the PCB-laden sediments, move them downstream, and redeposit them in another reach of the river. This process of PCB sorbtion to finegrained particles and movement downstream, deposition, resuspension, movement, and redeposition is responsible for the transport and the distribution of PCB's along the Housatonic River.

The highest concentrations of PCB's detected in the bottom sediments along the entire Housatonic River in Massachusetts, up to $140,000 \mu \mathrm{g} / \mathrm{kg}$, were found deposited in a stretch of the river between Pittsfield, Mass., and the Woods Pond Dam in Lenox, Mass. (fig. 5). Woods Pond is the first significant impoundment on the Housatonic River below Pittsfield that acts as an effective sediment trap. The pond was created when the Woods Pond Dam was built in 1901 (Frink and others, 1982). In Woods Pond, some of the highest concentrations of PCB's, up to $110,000 \mu \mathrm{g} / \mathrm{kg}$, were found in the black, organic bottom sediments. The thickness of this organic sediment ranges from 6 in. to $6 \mathrm{ft}$. From below the Woods Pond Dam to the Massachusetts-Connecticut State line, the concentration levels of PCB's in the bottom sediment decrease sharply but are as high as $9,600 \mu \mathrm{g} / \mathrm{kg}$. The higher concentrations of PCB's along this stretch of the river are in Rising Pond and in the oxbow sections of the river south of Rising Pond.

The significant decrease in PCB concentration in the river below Lee and Lenox, Mass., is attributed to the dam that creates Woods Pond (fig. 6). This impoundment has a relatively flat water-surface profile extending a considerable distance upstream from the dam. A flat water-surface profile is associated with low streamflow velocities, which, coupled with the profile's longitudinal extent, allow sufficient time for the fine-grained sediment in the river water to settle and collect on the bottom of the pond. The emerging wetland deposits at the inlet of Woods Pond are an indication that this abrupt change in velocity is ongoing.

The concentration of PCB's attached to the bottom sediments of Woods Pond differs considerably from place to place along the width and length of the channel. However, PCB concentrations in the bottom sediments of Woods Pond taken at 6-inch intervals vertically show a general pattern of sharp increase with depth to a maximum concentration in the 6- to 12-inch layer followed by a gradual decrease with increasing depth below the 6- to 12-inch layer. Through the application of the geologic principle of superposition (older layers are progressively overlain by younger layers), this sedimentary record provides a record of $\mathrm{PCB}$ concentration in sediments transported and deposited by the river in Woods Pond. It is interpreted to represent a history of gradual increase in the concentration of PCB's from the initial release of PCB's in the early 1930's to the mid1970's, when release of PCB's was sharply reduced. Even though PCB releases were sharply reduced, the top layer ( 0 to 6 in.) contains relatively high concentrations of PCB's. This is partly because less contaminated sediments resuspended from stream channels tributary to the Housatonic River are mixing with some of the resuspended, older stream-bottom sediments rich in PCB's, and partly because the lower part of the 6-inch layer may contain sediments from 


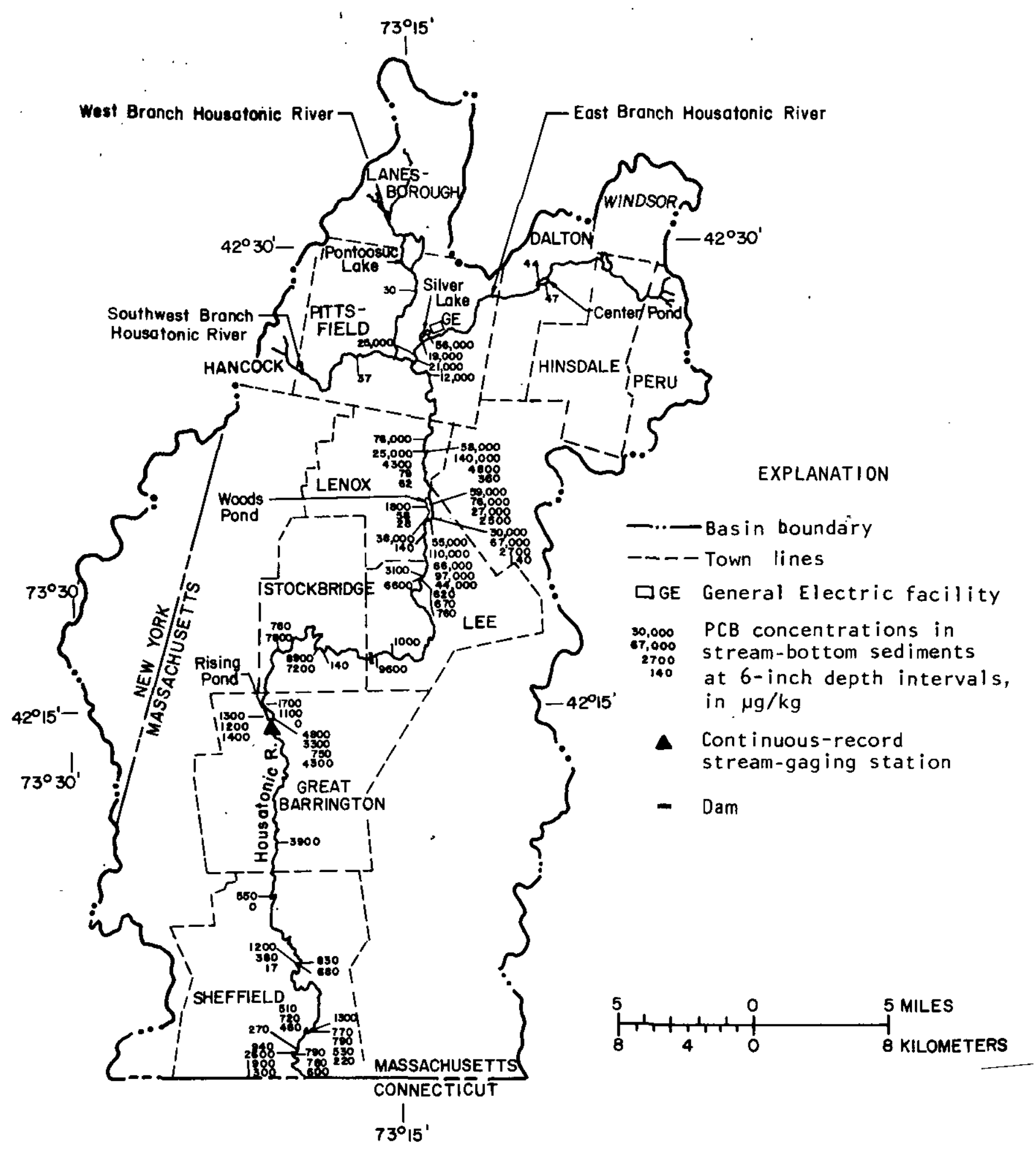

Figure 5. Concentration of PCB's sorbed to bottom sediments along the Southwest, West, and East Branch Housatonic Rivers and the Housatonic River in Massachusetts.

the period prior to the mid-1970's. This less contam- the availability of the more PCB-contaminated sediinated mixture of sediments is moving into Woods ments for erosion and transport downstream. Pond and burying the more contaminated PCB sedi- ments behind Woods Pond Dam. This process limits 
IN $\mu g / \mathrm{kg}$
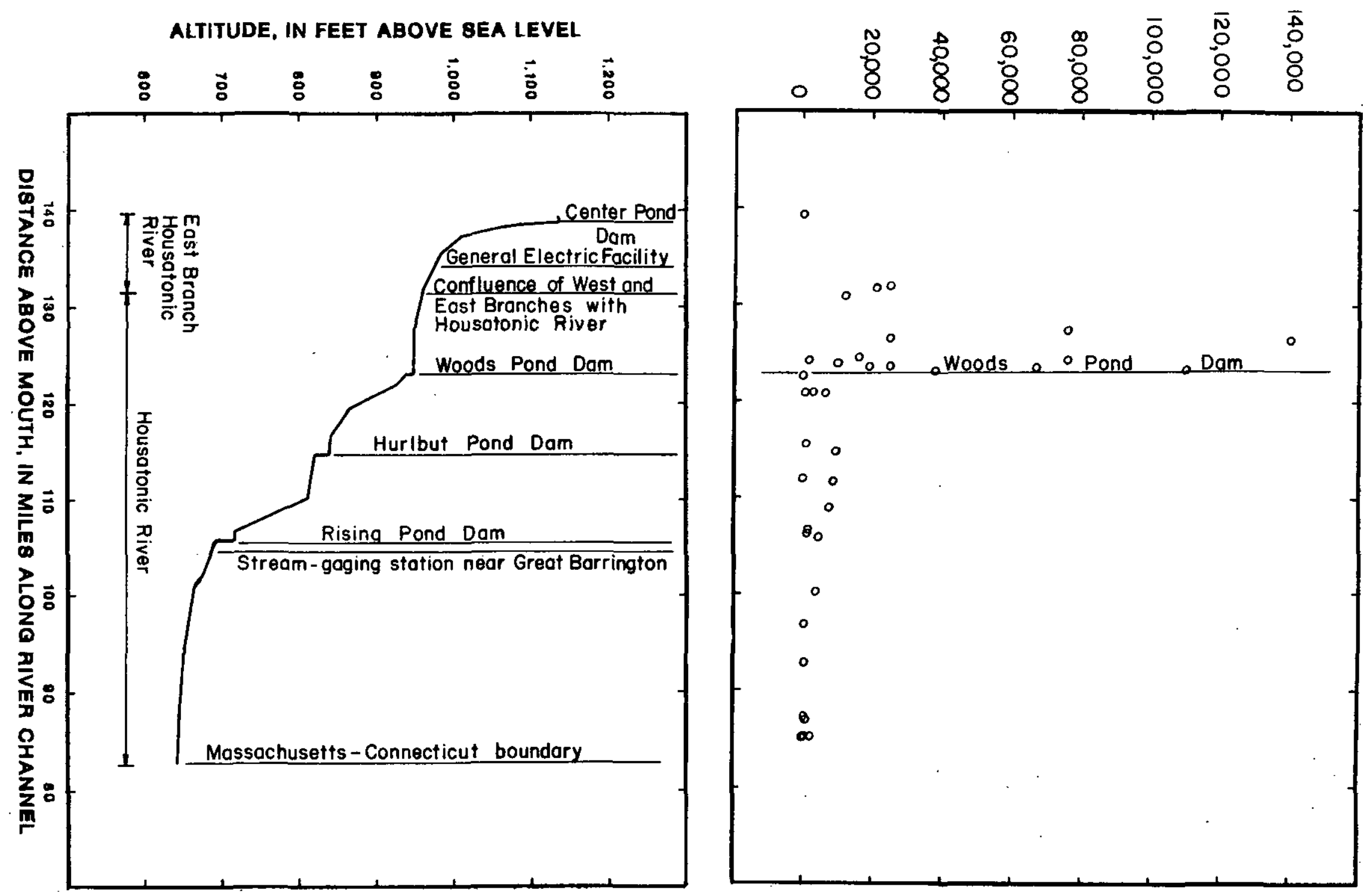

Figure 6. Maximum PCB concentration in bottom sediments and altitude above sea level of the water surface along the East Branch Housatonic River and the Housatonic River in Massachusetts. 
Particle-size analyses of samples of bottom sediments containing PCB's and organic carbon show that these sediments are composed of sand-sized or smaller particles. Total organic carbon in the bottom sediments along the Housatonic River in Massachusetts ranged from 2.2 to $320 \mathrm{mg} / \mathrm{L}$ (milligrams per liter). Although previous work has shown that PCB's have a strong affinity for the finer sized particles, particularly particles of organic carbon, neither this study nor the study by Frink and others (1982) made separate measurement of the PCB attachment to the individual grain sizes (sand, silt, or clay) or to the organic carbon.

Calculations made by Frink and others (1982) indicate that about 50 percent of all the PCB's in bottom sediments along the entire length of the Housatonic River are sorbed to the sediments that are lying behind the dam at Woods Pond. This amounts to about 11,000 pounds of PCB's. Whether or not any PCB-contaminated sediments trapped behind Woods Pond Dam would be eroded and moved downstream during a flood event is unclear. According to flood-prone areas delineated on the East Lee, Mass., 7.5-minute series topographic-quadrangle map (U.S. Geological Survey, 1969), the emerging wetland deposits in the Woods Pond area would be flooded occasionally. During these periods, it is unknown whether or not flood waters would have sufficient velocities to erode the PCB-contaminated sediments. However, should the dam at Woods Pond fail, part of the PCB-contaminated sediments trapped in the Woods Pond area would be transported downstream, especially during a flood.

\section{River Water}

Suspended-sediment concentration in stream water is highly variable owing to a number of factors that control the rate of sediment erosion and transport from its two main sources-the stream channel and the land surface drained by the stream channel. Some factors controlling sediment erosion and transport are (1) stream velocity, (2) particle size, shape, and specific gravity, (3) availability of erodable materials, (4) season of the year (frozen land surface), (5) amount and type of vegetative cover, (6) land use, (7) agricultural practices, and (8) intensity of rainfall and (or) snowmelt. Most of the following discussion focuses on the movement of stream-channel deposits.

Movement of stream-channel deposits depends on the energy exerted by the flowing water on the individual noncohesive or cohesive particles that make up the streambed materials. Noncohesive materials usually are composed of coarse-grained particles such as sand, and the resistance of this type of material to movement by flowing water is related to the size, shape, and specific gravity of the particle and to the slope of the streambed. Cohesive materials usually are composed of fine-grained particles such as clays, and the cohesive and adhesive forces, such as surface tension, between these fine-grained particles must be overcome before these particles can be suspended and transported. The force required to move cohesive particles is usually greater than that needed to maintain these particles in suspension. This phenomenon is clearly demonstrated by the Hjulstrom graph (Task Committee on Preparation of Sedimentation Manual, Commmittee on Sedimentation, 1966 , p. 299), which shows that the critical velocity necessary to suspend and to move clays and gravels from a streambed is higher than that needed to suspend and to move sand-sized particles from a streambed.

Normally, increased streamflow results in increased sediment transport and decreased streamflow results in decreased sediment transport. This is partly because (1) there is a direct relationship between streamflow and velocity, (2) there is a direct relationship between streamflow and wetted perimeter (cross-sectional length of streambed inundated by flowing water), (3) most streambed sediments are composed of a mixture of fine- to coarse-grained materials that will become suspended at various streamflow velocities, and (4) the stream channel receives sediment eroded from the land surface. Because most of the PCB's are sorbed to the bottom sediments along the Housatonic River, it is expected that these sediments will be suspended and moved downstream by streamflow when the proper velocities are reached for the various-sized particles. To estimate the amount of PCB's being transported downstream with the stream water, suspended-sediment concentrations were determined from daily samples collected at a continuous-record stream-gaging station near Great Barrington, Mass., about 20 river miles below Woods Pond Dam. In addition, dissolved and total concentrations of seven Aroclors of PCB's $(1016,1221,1232,1242,1248,1254$, and 1260) were determined in water samples collected from the river during some storm events. Because of the limited number of storms, as well as a lower than average flow, only a small number of samples were collected. Sixteen water samples were collected over a flow range of 235 to $2,980 \mathrm{ft}^{3} / \mathrm{s}$ and a suspendedsediment-concentration range of 18 to $226 \mathrm{mg} / \mathrm{L}$.

The concentration of dissolved material in water was determined from samples that had passed through a membrane filter having a $0.45 \mu \mathrm{m}$ (micrometer) pore size. The concentration of total material in water, both dissolved and suspended, was de- 
termined from unfiltered samples. The dissolved concentration was subtracted from the total concentration to determine the amount of PCB's sorbed to suspended-sediment particles greater than $0.45 \mu \mathrm{m}$ in diameter.

In the water samples taken at high flow near Great Barrington, only trace concentrations of total PCB's, less than $0.4 \mu \mathrm{g} / \mathrm{L}$, were found for the individual Aroclors of 1248, 1254, and 1260. Aroclor 1260 predominated in 15 of 16 samples. Aroclor 1248, the next most predominant Aroclor, was detected in 10 of 16 samples but in lower concentrations than Aroclor 1260. In contrast, Aroclor 1254 was found only in one sample. This is consistent with the stability of Aroclor 1260, as it has the most chlorine atoms, by weight, of the PCB compounds used by the General Electric Company in Pittsfield. Dissolved PCB's were found in 6 of the 16 samples, and at only 0.1 $\mu \mathrm{g} / \mathrm{L}$ for Aroclors 1248 and 1260 . The detection levels of the analytical methods used in the chemical analysis of both dissolved and total PCB's are 0.1 $\mu \mathrm{g} / \mathrm{L}$ (Wershaw and others, 1983). Aroclor 1248 was not reported to be used in Pittsfield (Frink and others, 1982), and its source is uncertain. However, the Environmental Criteria and Assessment Office (1980, p. A9) stated in reference to PCB's that "the purified product is a complex mixture of the chlorobiphenyls, the precise composition depending on the conditions under which the chlorination occurred." Therefore, it is possible that Aroclor 1248 was formed during the manufacturing process and was also present in either or both Aroclors 1254 and 1260 , which were reported to have been used in Pittsfield.

The sum of the total concentrations of Aroclors 1248,1254 , and 1260 did not exceed $0.6 \mu \mathrm{g} / \mathrm{L}$ for any samples. Subtracting the maximum concentration of dissolved PCB's $(0.1 \mu \mathrm{g} / \mathrm{L})$ from the maximum concentration of total PCB's $(0.6 \mu \mathrm{g} / \mathrm{L})$ indicates that most PCB's are sorbed to the suspended-sediment particles moving downstream. Frink and others (1982) have calculated that, even with this low concentration, about 490 pounds of PCB's move past the gaging station in Great Barrington each year.

Analyses of the suspended-sediment/PCB data at the Great Barrington gaging station show that a maximum of $0.6 \mu \mathrm{g} / \mathrm{L}$ of total PCB's was found in river water at streamflows up to $2,980 \mathrm{ft}^{3} / \mathrm{s}$. This low concentration indicates that very little of the PCBcontaminated sediments in the stream channel are eroded and moved downstream at streamflows of less than $3,000 \mathrm{ft}^{3} / \mathrm{s}$. It also indicates that streamflows greater than $3,000 \mathrm{ft}^{3} / \mathrm{s}$ would be required to move higher concentrations of PCB's downstream. However, flows of around $3,000 \mathrm{ft}^{3} / \mathrm{s}$ are not rare. For example, the annual peak streamflow will exceed $3,000 \mathrm{ft}^{3} / \mathrm{s}$ at intervals averaging 1.4 years, and the probability of the annual peak streamflow exceeding $3,000 \mathrm{ft}^{3} / \mathrm{s}$ in any " 1 year is about 70 percent (fig. 7). On a daily mean streamflow basis, this streamflow has been exceeded about 0.7 percent of the time (or about 170 days) during the last 68 years of record, as shown in figure 8 .

\section{HYDROGEOLOGY OF THE WOODS POND TEST SITE}

\section{Description}

A site at Woods Pond was chosen for the determination of the distribution of PCB's in ground water adjacent to the river because of the high concentration levels of PCB's in the pond's bottom sediments (fig. 9). Also, adjacent to the pond is a well field where three large-capacity industrial water-supply wells, pumping about $2 \mathrm{Mgal} / \mathrm{d}$, have operated almost continuously since late 1965 . These wells are owned and operated by the P. J. Schweitzer Division, Kimberly-Clark Corporation, located in Lee, Mass. Analysis of water-level data collected from a wellperformance test conducted on No. 3 production well in 1965 (Geraghty and Miller, 1965) and from an - aquifer test conducted by the Survey in December 1981 indicates that all three wells induce river water into the aquifer along the south shore of Woods Pond. The first two production wells (Nos. 1/4 and 2) have been pumping water since late 1956. Thus, river water has been induced to flow through PCBladen bottom sediments in Woods Pond and into the aquifer for about 25 years at the time the aquifer materials and ground water were sampled.

The sand and gravel aquifer at the well site is a kame terrace, an ice-contact deposit that constricts the Housatonic River's flood plain from $2,000 \mathrm{ft}$ wide in the center of Woods Pond to $200 \mathrm{ft}$ wide near the outlet of Woods Pond (fig. 10). This deposit extends from about $110 \mathrm{ft}$ below to as much as $110 \mathrm{ft}$ above river level (fig. 10) and is about $0.54 \mathrm{mi}^{2}$ in areal extent.

The surface of this deposit is irregular and is marked by several terraces and kettle holes. The deposit is composed of stratified sand containing lenses of silt and gravel. It was deposited about blocks of ice by streams and in ponds of melt water to the south of a large tongue of glacial ice melting in the river valley at the present location of Woods Pond. As a result of its lithologic heterogeneity, the aquifer's hydraulic conductivity is also highly variable. The aquifer has been identified by Geraghty and 
PROBABILITY OF OCCURRENCE, IN PERCENT

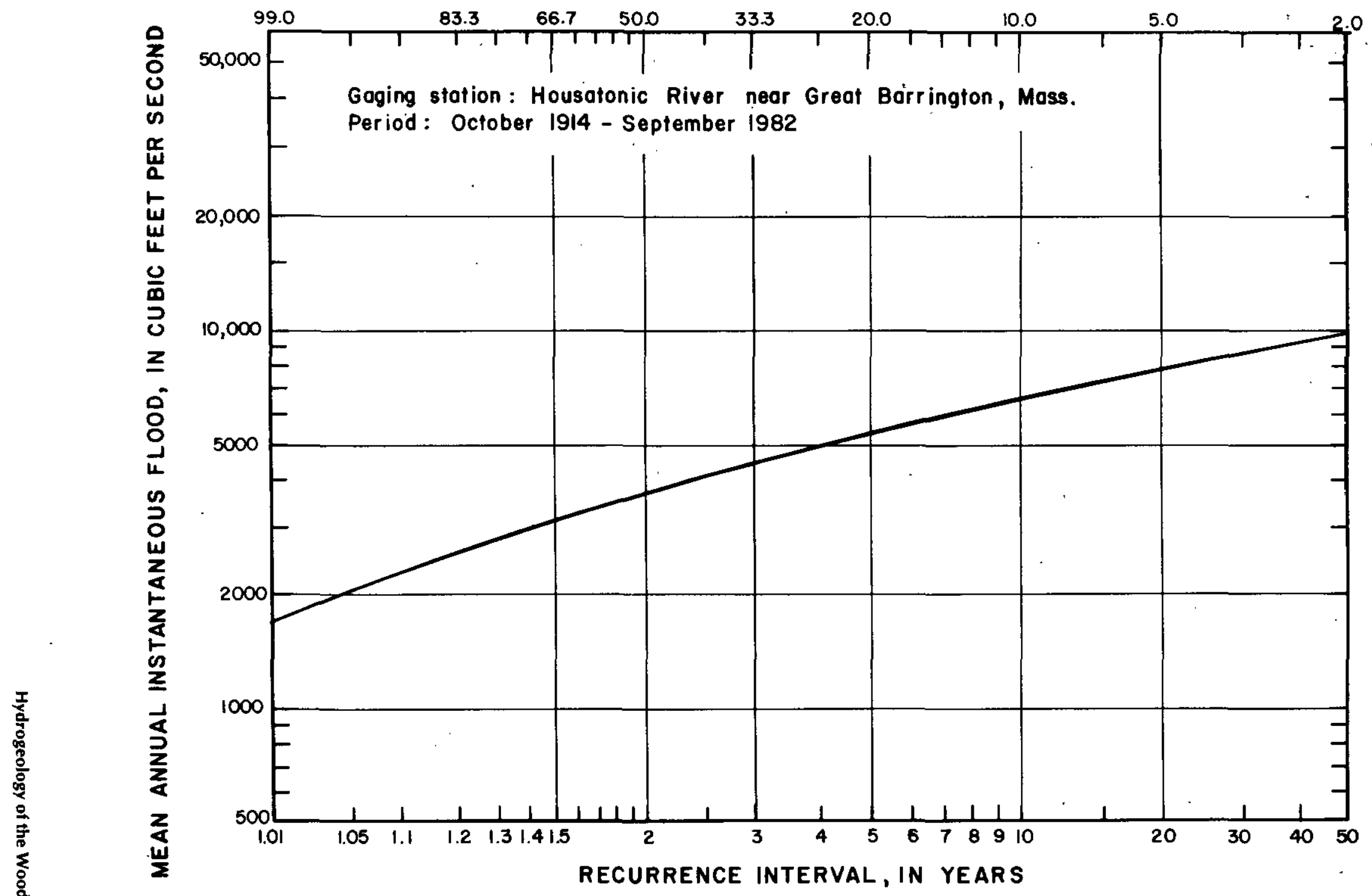

Figure 7. Annual peak-streamflow frequency curve for the Housatonic River near Great Barrington gaging station for water years 1914-82. 


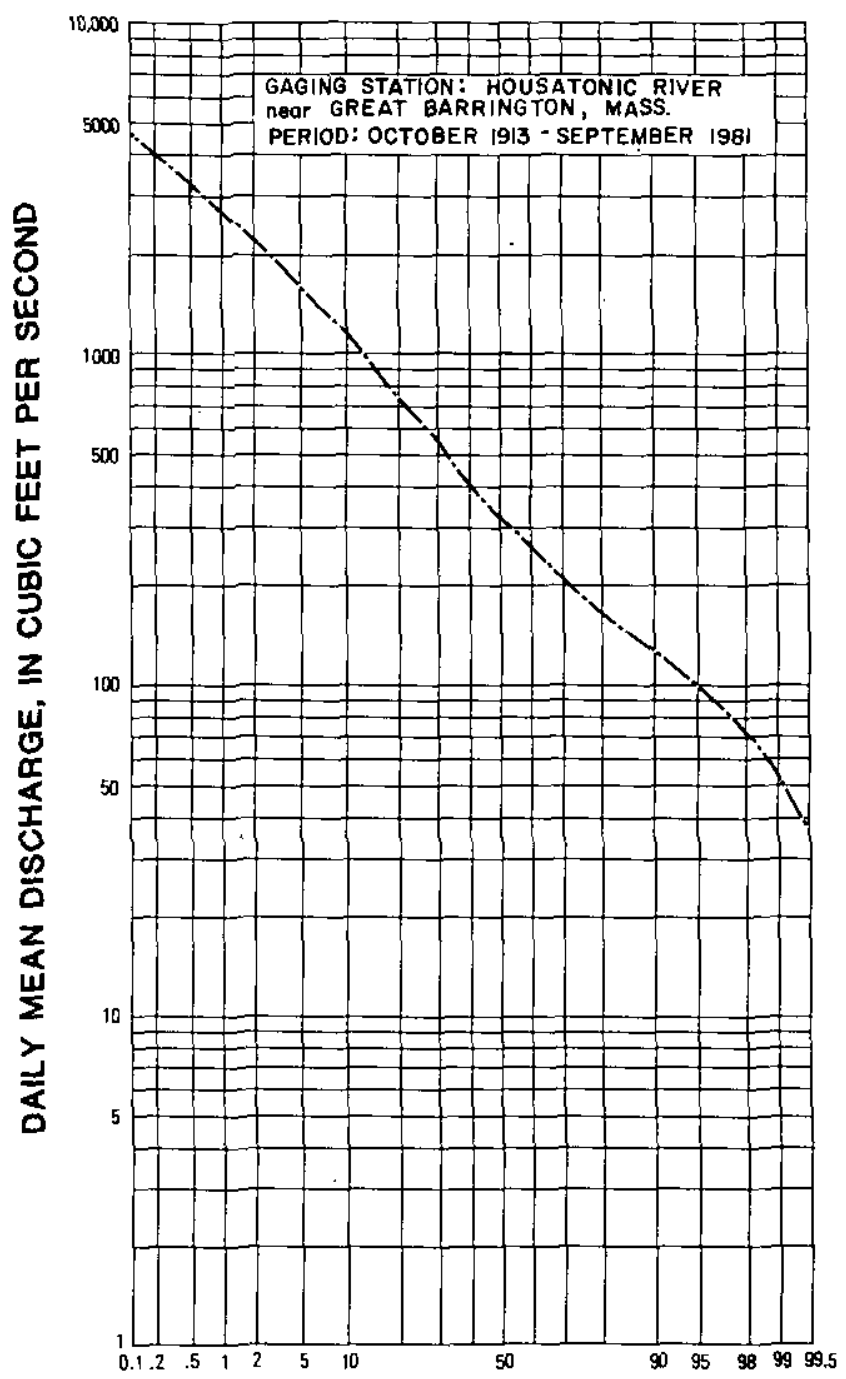
PERCENTAGE OF TIME INDICATED DISCHARGE
WAS EQUALED OR EXCEEDED

Figure 8. Flow-duration curve for the Housatonic River near Great Barrington gaging station for water years 1914-81.

Miller (1965), Norvitch and others (1968), and Motts (1972) as a potential high-yield source of water. The saturated thickness of the deposit is estimated to be as much as $110 \mathrm{ft}$, and Motts (1972) estimated that it could yield more than $5 \mathrm{Mgal} / \mathrm{d}$.

The quantities of water derived from different sources of water by wells pumping from part of this aquifer can be estimated from a water-balance analysis. Sources of inflow to the sand and gravel aquifer are (1) direct recharge from precipitation onto the kame terrace, (2) recharge of overland runoff from the adjacent till and bedrock upland area onto the kame terrace, (3) leakage of ground water from the till and bedrock into the kame terrace, and (4) in- duced infiltration from Woods Pond and the Housatonic River into the kame terrace. An inflow of 2 $\mathrm{Mgal} / \mathrm{d}$ is needed from all these sources to balance the $2 \mathrm{Mgal} / \mathrm{d}$ withdrawal by the three industrial water-supply wells. Ground-water recharge through sandy soils receiving similar amounts of precipitation is estimated to be about $1\left[(\mathrm{Mgal} / \mathrm{d}) / \mathrm{mi}^{2}\right]$ (Cohen and others, 1968; Guswa and LeBlanc, 1981). The area of the sand and gravel aquifer that contributes water to the wells is about $0.20 \mathrm{mi}^{2}$. This area of the aquifer (fig. 10) is bounded on the east by till and bedrock, on the north by Woods Pond, on the west by the Housatonic River, and on the south by a groundwater divide whose approximate location was determined on the basis of water levels in observation wells from two aquifer tests conducted in March/April and August 1979. These aquifer test data are in the files of the Massachusetts Division of Water Resources. Because the land surface area of this sand and gravel aquifer (kame terrace) is about $0.20 \mathrm{mi}^{2}$, the recharge to it directly from precipitation is estimated to be about $0.20 \mathrm{Mgal} / \mathrm{d}$. The potential contributing drainage area of till and bedrock upland east of the aquifer is about $0.64 \mathrm{mi}^{2}$. Because the mean annual runoff from similar terraces in the Berkshire Highlands (Sykes Brook gaging station at Knightville, Mass., in the Westfield River basin) is $0.96\left[(\mathrm{Mgal} / \mathrm{d}) / \mathrm{mi}^{2}\right]$, the runoff from this contributing upland area is estimated to be about $0.60 \mathrm{Mgal} / \mathrm{d}$. The mean annual ground-water leakage from till and bedrock to sand and gravel aquifers in New England has been estimated to be about $0.30\left[(\mathrm{Mgal} / \mathrm{d}) / \mathrm{mi}{ }^{2}\right]$ (Morrissey, 1983). Therefore, the potential groundwater leakage to the aquifer is about $0.20 \mathrm{Mgal} / \mathrm{d}$. The total recharge to the aquifer, exclusive of induced recharge, is therefore about $0.20+0.60+0.20$ $\mathrm{Mgal} / \mathrm{d}$, or $1.0 \mathrm{Mgal} / \mathrm{d}$. To balance the withdrawal rate of $2 \mathrm{Mgal} / \mathrm{d}$, an additional $1.0 \mathrm{Mgal} / \mathrm{d}$ as induced infiltration from Woods Pond and the Housatonic River is required. From this water-balance analysis, it is estimated that a significant quantity (about half) of the water withdrawn by the wells is derived from Woods Pond and the Housatonic River. If PCB's could be induced to migrate from the river and pondbottom sediments, this field laboratory site should show evidence of PCB's in ground water. In a later section of this paper, geochemical evidence is also used to demonstrate that water from the Housatonic River and Woods Pond is induced to infiltrate the aquifer and is produced by the wells.

\section{Ground-Water Sampling Network}

Eleven observation wells were installed along the south edge of Woods Pond opposite a previously 


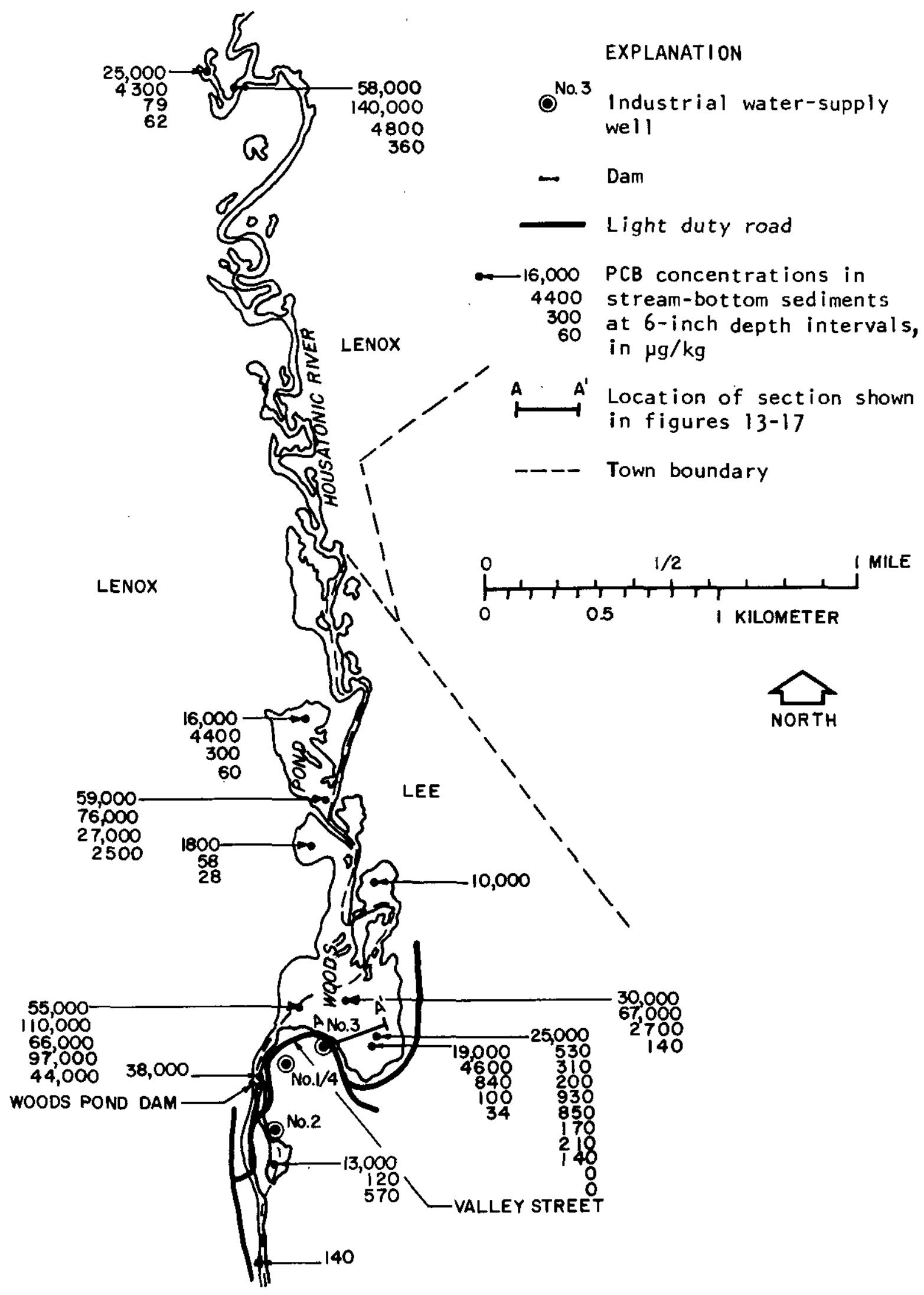

Figure 9. Concentration of PCB's sorbed to bottom sediments in Woods Pond and immediately upstream and downstream. 

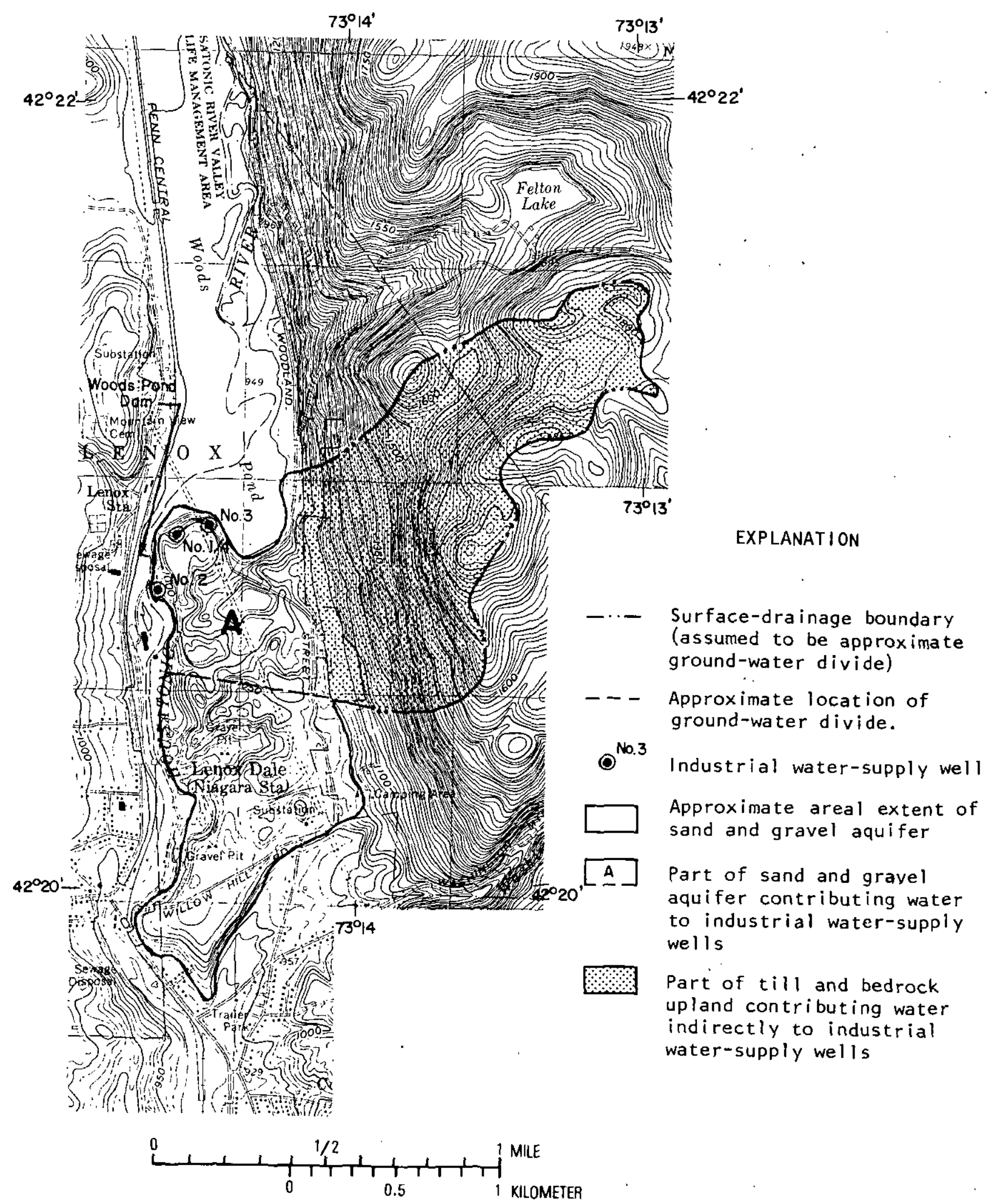

Figure 10. Locations of industrial water-supply wells and areal extent of the aquifer. 


\section{EXPLANATION}

No.3

Industrial water-supply well

Q Observation well
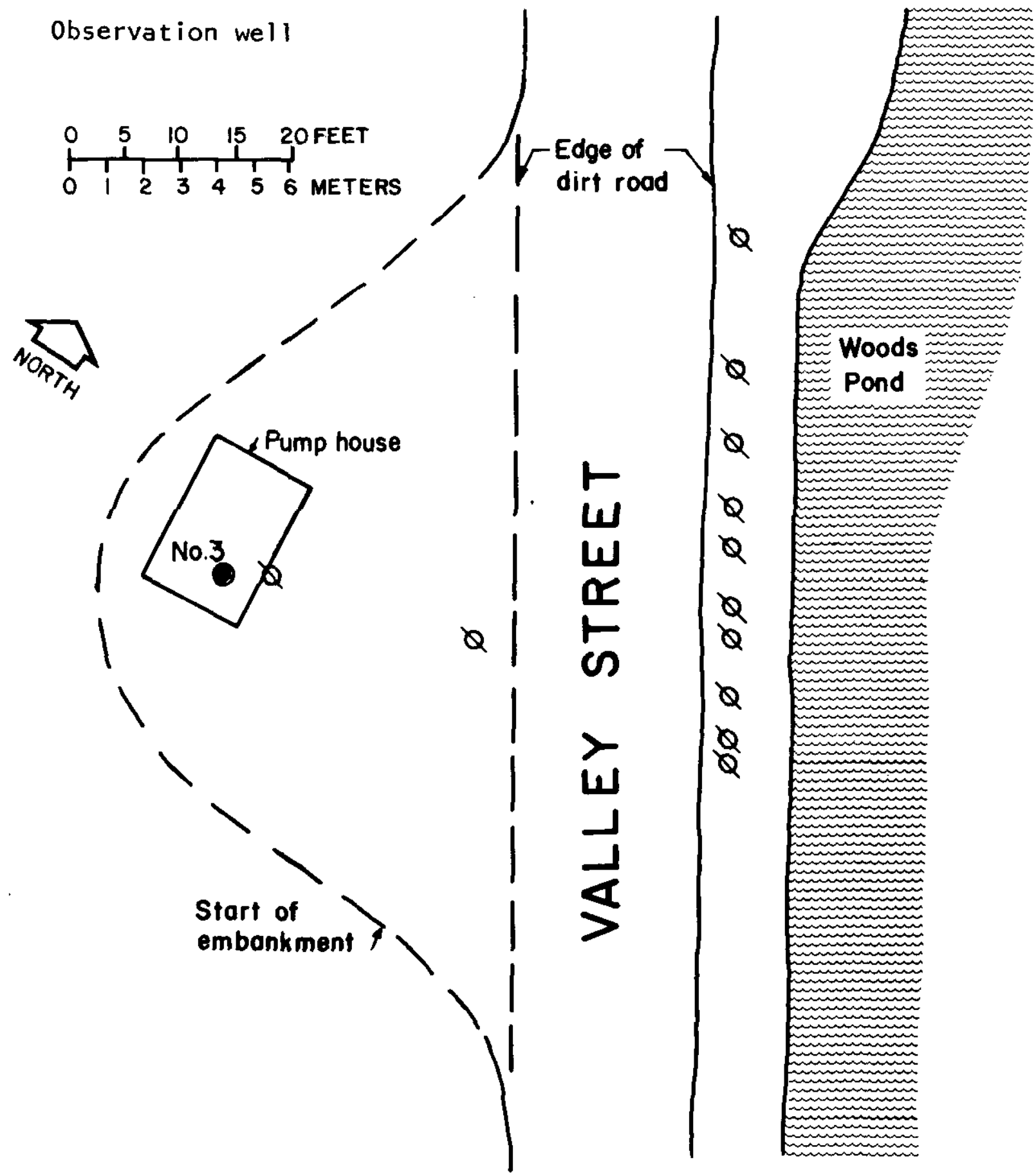

Figure 11. Location of the observation-well network used to sample for PCB's in the aquifer adjacent to Woods Pond.

installed No. 3 production well and an observation well located adjacent to the pump house (fig. 11). All 13 wells shown in figure 11 were used either to collect water-quality samples or to measure hydraulic heads in the aquifer or both. Ten of the 11 observation wells were completed in test holes drilled about $5 \mathrm{ft}$ from the edge of Woods Pond. In addition to these 11 wells, 3 other observation wells were installed 


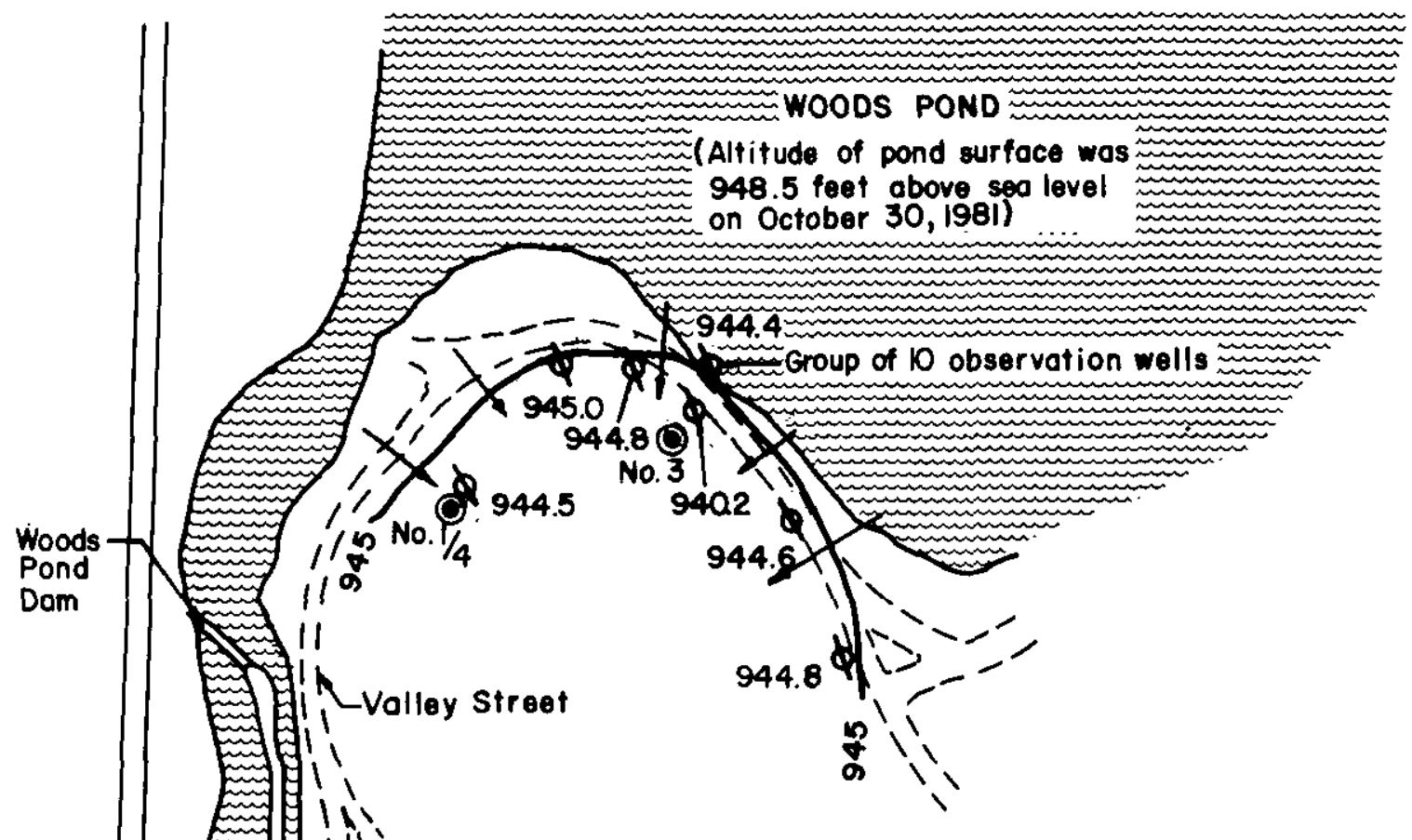

EXPLANATION

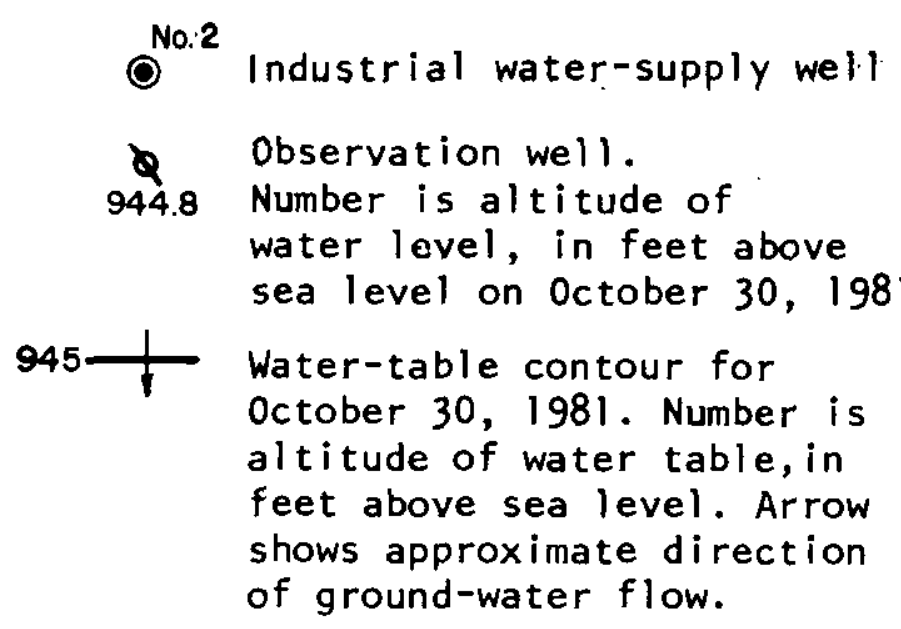

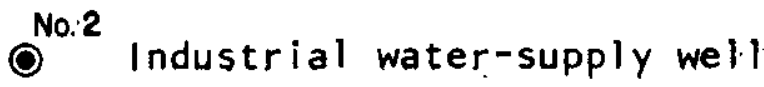
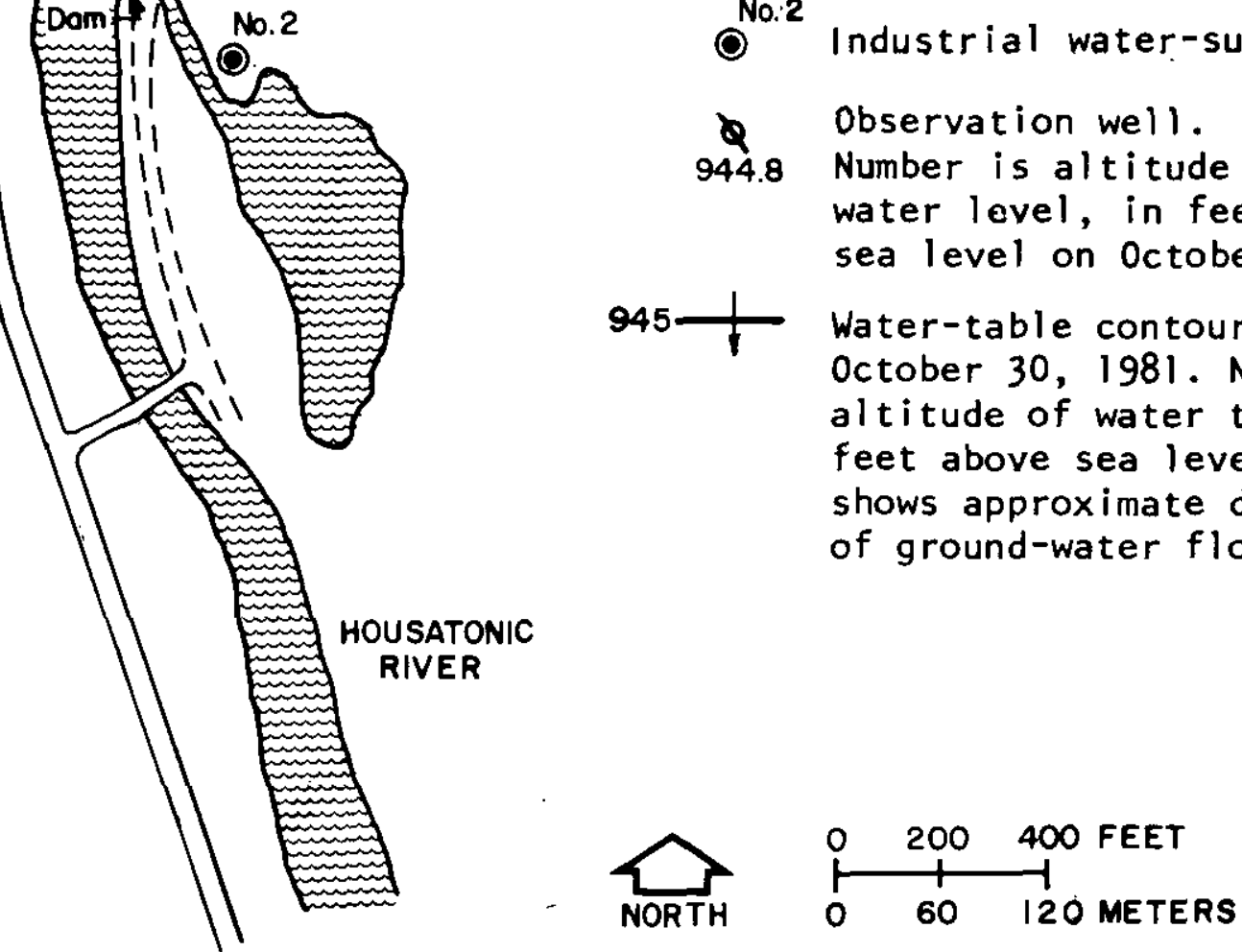

Figure 12. Location of wells, altitude of water table, and direction of ground-water flow in the aquifer adjacent to Woods Pond.

along Valley Street to augment other observation wells (fig. 12) installed during previous investigations (Geraghty and Miller, 1965). All these wells were used to measure hydraulic heads in the aquifer.
Several precautions were taken during well installation to prevent PCB contamination of the aquifer. Individual wells were placed in separate test holes augered to just above the depths where the. well 


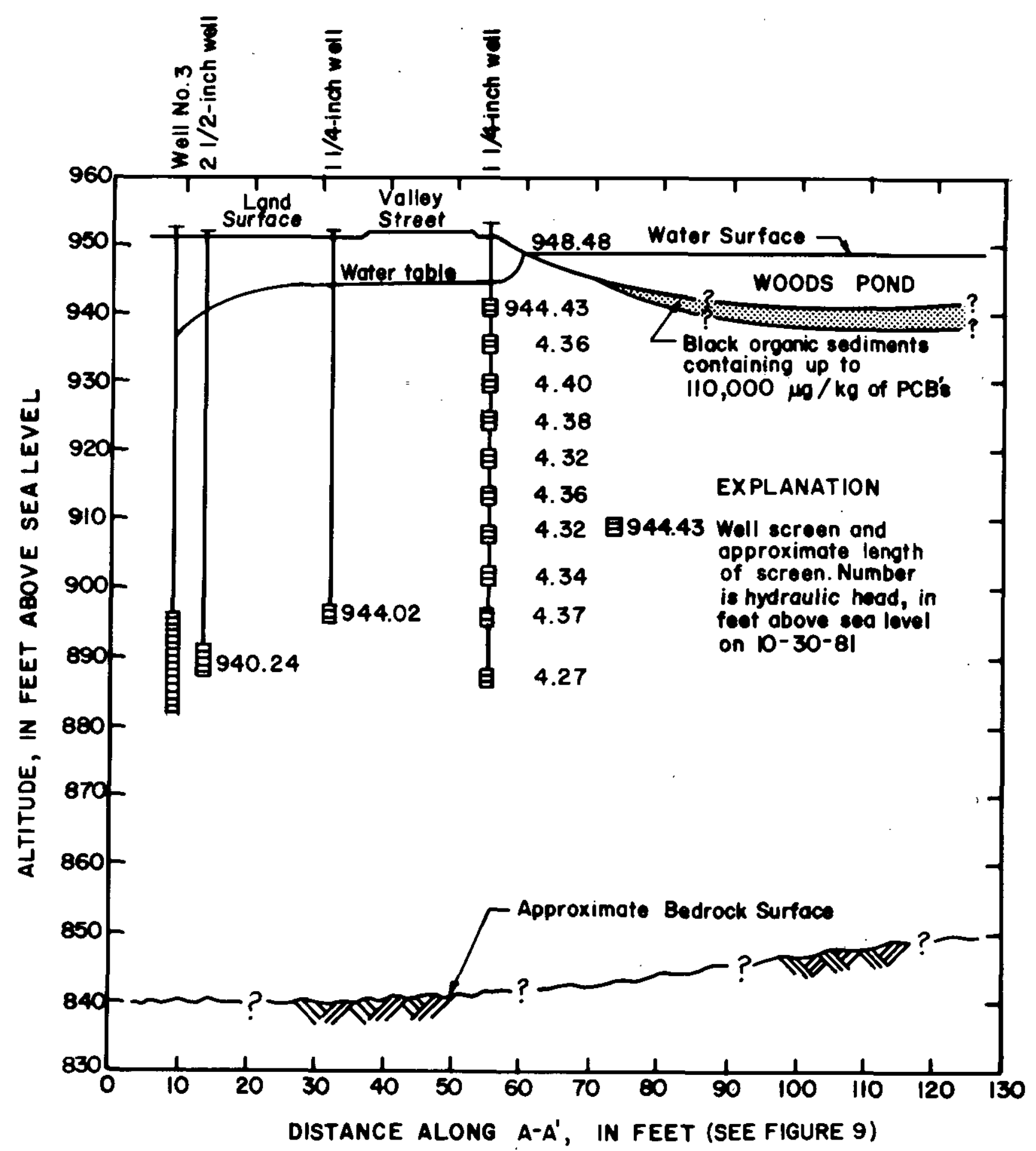

Figure 13. Locations of well screens and distribution of hydraulic head in the aquifer adjacent to Woods Pond.

screens were to be placed. Prior to placement of the well screens at selected depths in the aquifer, a splitspoon sample of aquifer material was collected for PCB analysis. The 10 observation wells parallel to the shore of Woods Pond were screened at different depths in the aquifer, ranging from just below the water table to depths equal to about the center of No. 3 well screen, as shown in figure 13 . The 2.5 -foot well screens were installed so that there was about $3 \mathrm{ft}$ between the bottom of one screen and the top of the next deeper screen. An additional well was placed about halfway between this line of wells and No. 3 
production well and was screened at the same depth as the production well screen to determine any changes in PCB concentrations with respect to distance between the pond and the production well. The observation wells not shown in figure 13 were screened at depths similar to that of the production well.

All the wells installed for this study were constructed of galvanized steel (pipe, couplings, caps, and well screens) $1 \frac{114}{4}$ in. in diameter. Before the wells were installed, all items were washed with detergent and water and were rinsed with reagent-grade hexane to remove any traces of oil used during the pipe cutting and threading processes. Hexane was used to dissolve and remove any traces of PCB's that might have been present as a contaminant in the cutting oil. In addition, the split-spoon sampler was washed with hexane before the aquifer samples were collected. Teflon tape was used to make watertight seals at the pipe joints. At each connection, care was taken to prevent exposing this tape on the inside of the pipe. To prevent water from moving down along the outside of the steel pipe and into the aquifer opposite the well screen, a one-pellet-thick layer of $1 / 2$-inch bentonite pellets about $2 \mathrm{ft}$ long was secured around the steel pipe about $2 \mathrm{ft}$ above the well screen with $1 / 4$ inch mesh steel hardware cloth. These pellets swell to about 10 times their normal size when exposed to water and fill any void space between the pipe and the adjoining aquifer material.

\section{Ground-Water Flow}

The direction of ground-water flow in the water-table aquifer, as well as the locations of the 16 observation wells and the 3 industrial water-supply wells used to determine the general ground-water flow pattern in this study, are shown in figure 12 . Before the industrial water-supply wells were operated at the site, the altitude of the water table would have been above that of Woods Pond and groundwater discharge would have been to the pond. However, continuous pumping of all three industrial water-supply wells has reversed the direction of ground-water flow by lowering the water table to below the level of Woods Pond. Water from Woods Pond now infiltrates the bottom sediments and enters the aquifer. Water-level data from the wells located about $5 \mathrm{ft}$ from the edge of Woods Pond indicate that a 4-foot decrease in hydraulic head occurs near the edge of the pond (fig. 13). Away from the pond's edge, the water table slopes gradually toward the production well and steepens next to the well. Groundwater flow within the upper part of the aquifer is essentially horizontal and toward the production well. There is a slight decrease in hydraulic head with depth, indicating that there is some downward movement of ground water toward the production well screen.

\section{Surface-Water/Ground-Water Interaction}

Physical and chemical data, including variations in water temperature, and concentrations of dissolved oxygen, ammonia, iron, and manganese show that water from Woods Pond is moving into the aquifer and is discharging at the production well. Ammonia $\left(\mathrm{NH}_{3}\right)$ and ammonium $\left(\mathrm{NH}_{4}\right)$ ion are referred to as ammonia in this paper.

Water temperatures measured in Woods Pond and in the 10 observation wells adjacent to Woods Pond on September 3-4, 1981, show a gradual decrease with increasing depth within the aquifer, from $21.0^{\circ} \mathrm{C}$ in the pond to $9.0^{\circ} \mathrm{C}$ in the lower part of the aquifer (fig. 14). In the Housatonic River basin, the normal temperature of discharging ground water (spring water) whose source is direct recharge from precipitation is around $9.5^{\circ} \mathrm{C}$ (Collins, 1925, pl. VIII). Collins concluded that ground water not affected by thermal activity and moving between 30 and $60 \mathrm{ft}$ below ground surface has a temperature somewhere between $1.1^{\circ}$ and $1.7^{\circ} \mathrm{C}$ above the area's mean annual air temperature. In western Massachusetts, the mean annual air temperature is about $7.8^{\circ} \mathrm{C}$ (U.S. Department of Commerce, 1969). If ground water were discharging to Woods Pond in this area, water temperatures throughout the aquifer would have a relatively uniform temperature of about $9^{\circ} \mathrm{C}$, as exemplified by the water moving in the lower part of the aquifer. Water in an aquifer receiving induced recharge from a stream or an impounded reach of a stream, such as Woods Pond, follows the yearly temperature variations of stream water (about $0^{\circ}$ to $21^{\circ} \mathrm{C}$ ) but generally has a smaller range and lags behind the changes in stream-water temperature. Both the September 3-4 and the October 27, 1981, profiles (fig. 14) are examples of this temperature variation. The September profile shows elevated ground-water temperatures near the pond owing to infiltration of warmer water from Woods Pond. The October profile, although essentially the same, is beginning to show the cooling effects of induced recharge of much cooler water from Woods Pond, particularly in the upper $10 \mathrm{ft}$ of saturated thickness. These temperature profiles demonstrate that water from Woods Pond is recharging the upper $40 \mathrm{ft}$ of the aquifer.

The distribution of dissolved oxygen $\left(\mathrm{O}_{2}\right)$, ammonia, and nitrate concentrations in water from 


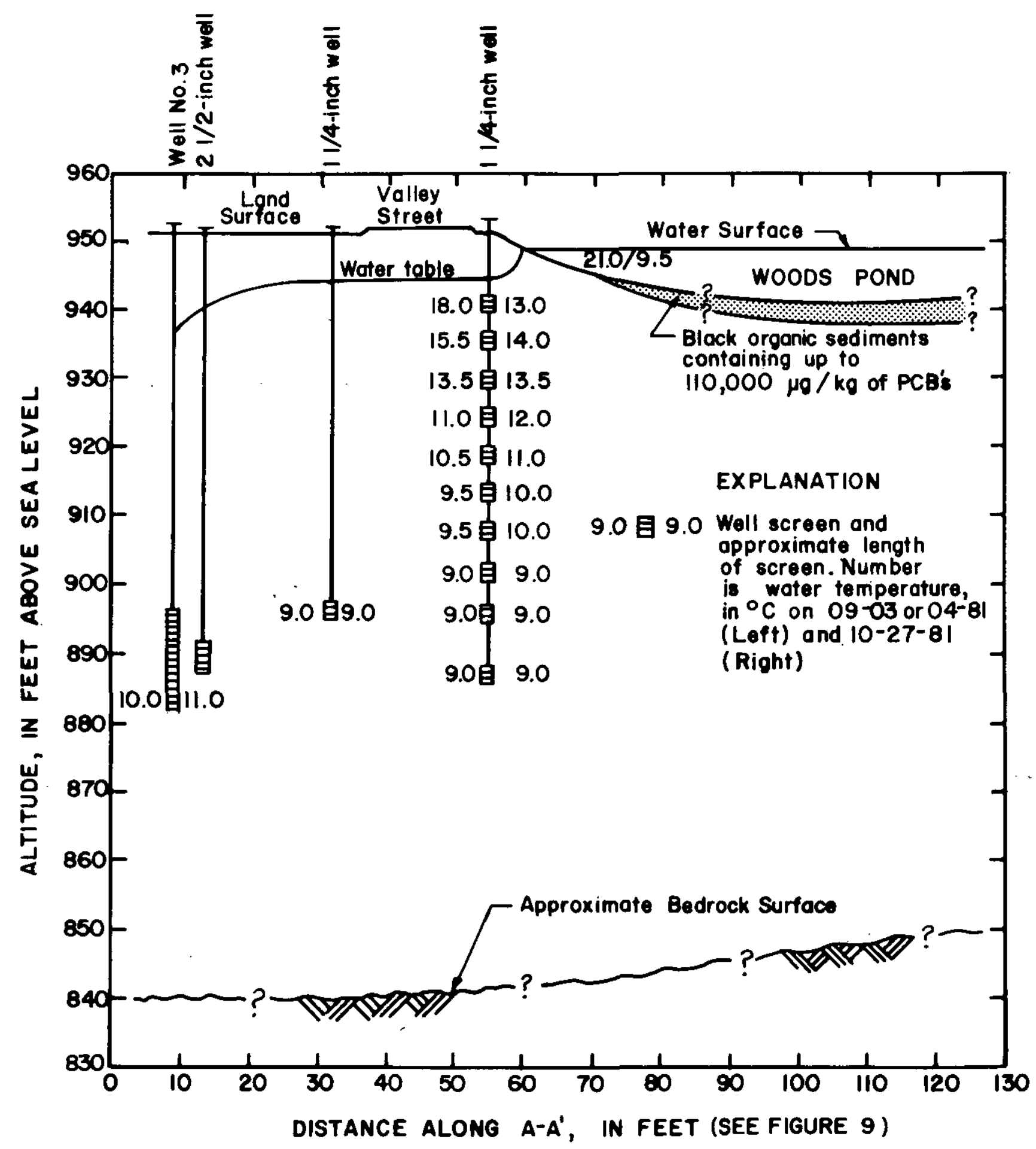

Figure 14. Distribution of water temperature in Woods Pond and adjacent aquifer.

these observation wells (figs. 15 and 16) is interpreted to indicate that the water from Woods Pond is recharging the aquifer. As oxygenated water in Woods Pond passes through the 6-inch-thick to 6foot-thick layer of black organic sediments, oxygen in the water is consumed in the decomposition of organ- ic matter. During this decomposition process, ammonia is formed. However, ammonia, a reduced form of nitrogen, can be converted to nitrate $\left(\mathrm{NO}_{3}{ }^{-}\right)$ ion, a more oxidized form of nitrogen, by reacting with dissolved oxygen, such as is found in the lower part of the aquifer. The absence of dissolved-oxygen 


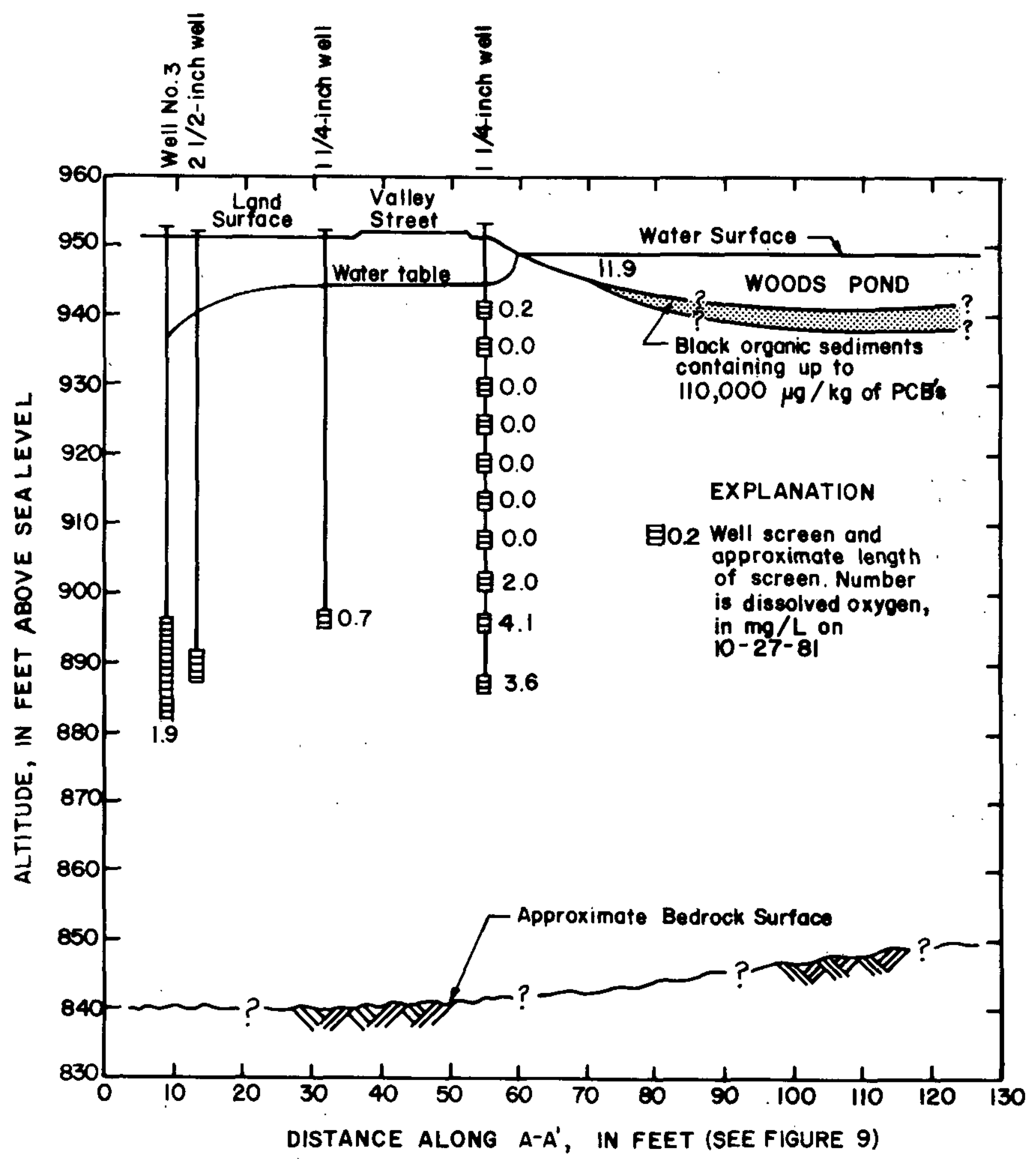

Figure 15. Distribution of dissolved oxygen in Woods Pond and adjacent aquifer.

concentrations (mostly $0.0 \mathrm{mg} / \mathrm{L}$ ) and the high ammonia concentrations (as much as $1.2 \mathrm{mg} / \mathrm{L}$ ) in water pumped from the uppermost seven wells near the edge of Woods Pond indicate that this upper zone of the aquifer contains water that is being recharged through the bottom of Woods Pond. In Massachu- setts, water in water-table aquifers normally contains dissolved oxygen, some nitrate, and very little, if any, ammonia. For example, ground water recharged from precipitation through sandy soil on Cape Cod, Mass., has median values of $7.0 \mathrm{mg} / \mathrm{L}$ of dissolved oxygen, $0.01 \mathrm{mg} / \mathrm{L}$ of ammonia as nitrogen, and 0.12 


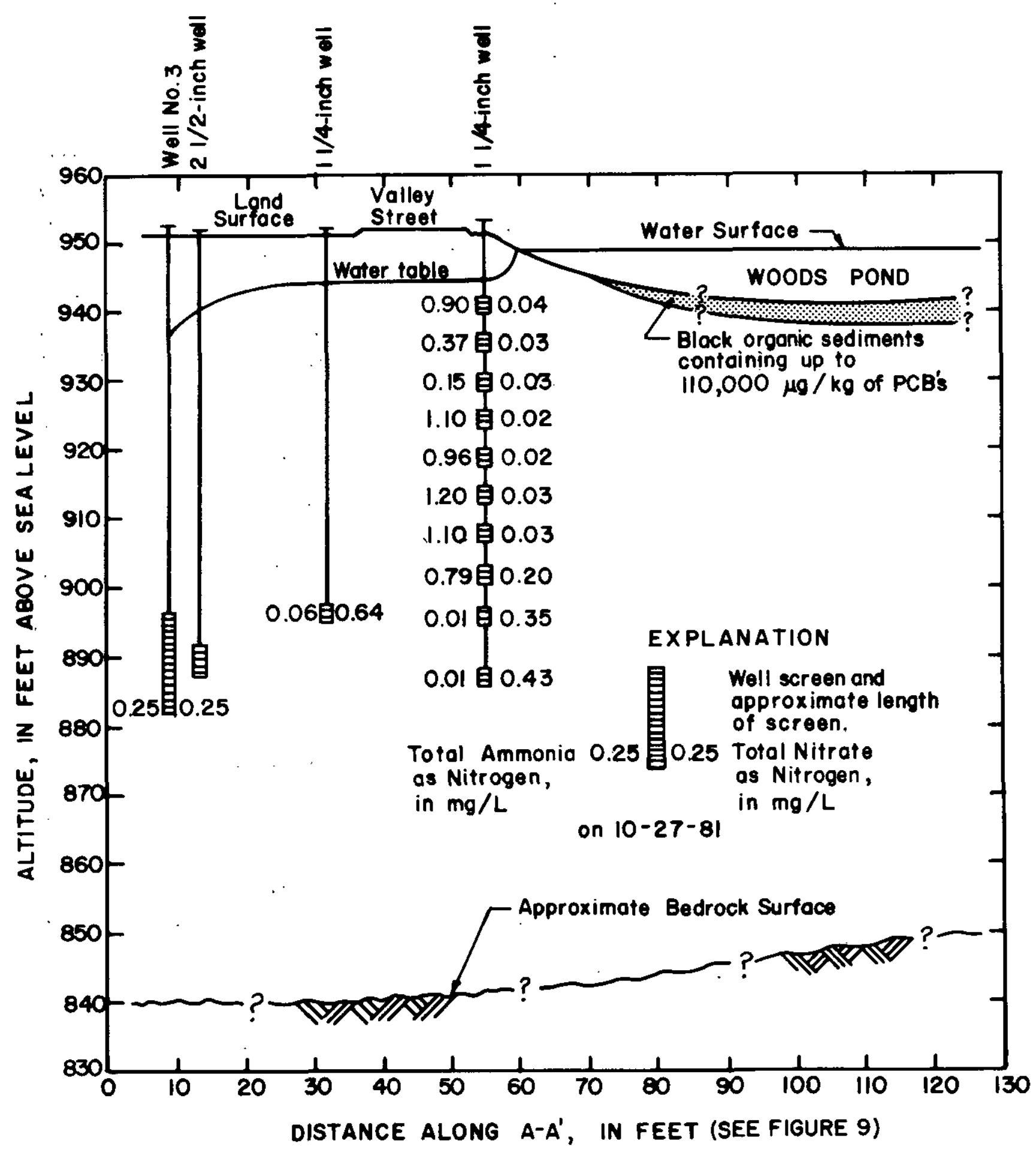

Figure 16. Distribution of total ammonia and nitrate ions in the aquifer adjacent to Woods Pond.

$\mathrm{mg} / \mathrm{L}$ of nitrate as nitrogen (Frimpter and Gay, 1979).

It is inferred from the absence of dissolved oxygen and the elevated concentrations of ammonia found in the water infiltrated through the pond's bottom sediments that this water has a low oxidation potential. Water having a low oxidation potential is capable of dissolving metals (particularly iron and manganese) during its passage through an aquifer (Frimpter and Gay, 1979). At Woods Pond, the highest concentrations of both iron and manganese are present in the zone identified as containing in- 


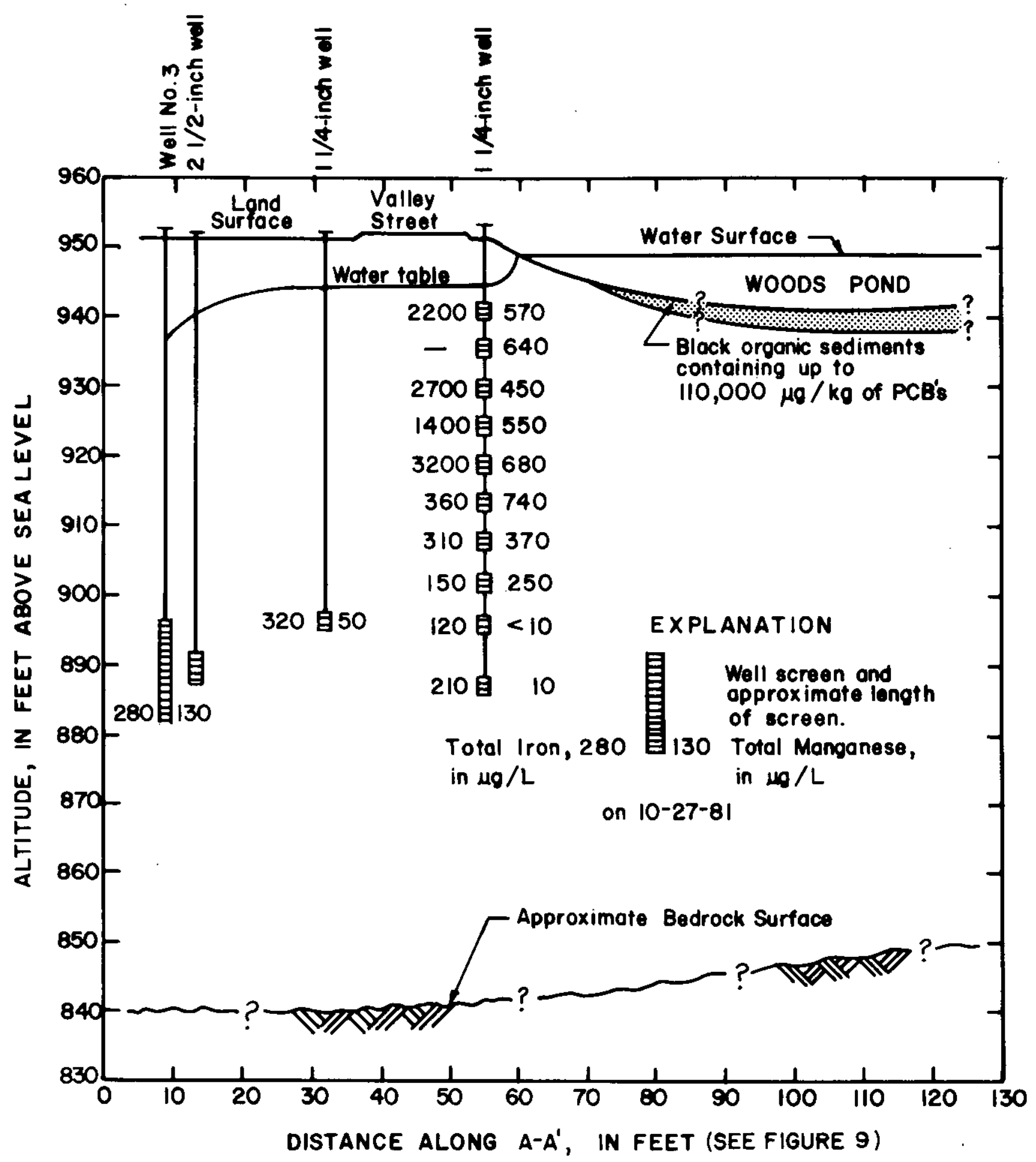

Figure 17. Distribution of total iron and manganese in the aquifer adjacent to Woods Pond.

duced recharge from the pond (fig. 17). This condition of mobilization of metals by ground water derived from induced infiltration is an explanation of the common problem of high iron and manganese concentrations found in some municipal and industrial water-supply wells in New England (Frimpter,
1973; Silvey and Johnston, 1977). It is an explanation of why such wells that initially yield water having low concentrations of iron and manganese may later yield water having high concentrations of these metals. Initially, the wells capture oxygenated water recharged from precipitation, but prolonged pump- 
ing reverses the direction of ground-water flow and some water is derived from induced infiltration through a reducing zone. The dissolved constituents in the water are transported from their sources by the flowing (velocity) ground water along flow paths determined by the hydraulics of the ground-water-flow system, a process called "advection" (a movement process).

The values of water temperature, dissolved oxygen, ammonia, nitrate, iron, and manganese in the top seven wells show that the source of the water flowing past these well screens is Woods Pond. Only in the lower levels of the aquifer is there water having higher values of dissolved oxygen $(2.0$ to $4.1 \mathrm{mg} / \mathrm{L})$ and lower values of water temperature $\left(9^{\circ} \mathrm{C}\right)$. These values of dissolved oxygen and water temperature indicate that some of this ground water is direct recharge from precipitation, probably from the east side of Woods Pond. This water would normally discharge into Woods Pond but is being diverted toward the well field by the continuous pumping of the three industrial water-supply wells. The dissolved constituents in this water are being mixed with the dissolved constituents in the water moving through the bottom of Woods Pond by a process called "hydrodynamic dispersion" (a spreading process) which has created a transition zone between pond water recharged through Woods Pond and ground water recharged directly through the soil from precipitation. According to LeBlanc (1982), "dispersion results from mechanical mixing as ground water moves through the tortuous, branching, and interfingering pores of different sizes between the sediment grains and from molecular diffusion in the pore water." Water containing the concentrations of dissolved oxygen found in the lowermost wells will oxidize iron, manganese, and ammonia, resulting in a significant decrease in their concentrations. Iron and manganese in the water in the transition zone have been precipitated and redeposited in the aquifer, and ammonia has been oxidized to nitrate. These oxidation reactions have also lowered the concentration of dissolved oxygen in the transition zone.

\section{EFFECT OF POLYCHLORINATED BIPHENYLS IN RIVER SEDIMENTS ON ADJACENT GROUND WATER}

The hydraulic heads in the aquifer adjacent to the pond, together with the water-temperature gradients, dissolved-oxygen concentration, and other water chemistry of the pond and the aquifer, indicate that pond water recharges the aquifer in response to pumping, as described above.
Chemical analyses of the aquifer material from selected intervals throughout a vertical section of the aquifer $(10,21,32,44,55$, and $64 \mathrm{ft}$ below land surface) $5 \mathrm{ft}$ from the edge of Woods Pond show that PCB concentrations are less than the detection limit of the analytical method, $1.0 \mu \mathrm{g} / \mathrm{kg}$ (Wershaw and others, 1983). If PCB's had moved through these sediments in the past, PCB's would be expected to have sorbed to the fine-grained materials owing to PCB's strong affinity for fine-grained particles-and they have not.

PCB's were not detected in ground water. Chemical analyses of water from the eleven $11 / 4$-inchdiameter observation wells located between the pond and production well No. 3 and from the production well did not detect PCB's in either the dissolved or the suspended phase, at the detection limit of the analytical method used, $0.1 \mu \mathrm{g} / \mathrm{L}$ (Wershaw and others, 1983).

The absence of PCB's from both the aquifer material and water samples, particularly in the dissolved phase, indicates that PCB's have not passed through the aquifer from the pond's bottom sediments and have not reached a vertical section of the aquifer $5 \mathrm{ft}$ from the edge of Woods Pond or the more distant production wells after 25 years of induced infiltration. If PCB's were mobilized by chemical and physical conditions present in the bottom sediments and moved deeper through the bottom sediments along with pond water flowing into the aquifer, the highest concentrations of PCB's should be in the bottom layer of sediments rather than near the top layer, as is currently the case. Therefore, it is concluded that PCB's are not passing into and through the aquifer material from the pond's bottom sediments and, furthermore, that reducing conditions in the bottom sediments of Woods Pond do not favor the movement of PCB's into the aquifer.

The ponded environment at Woods Pond represents a worst case scenario, where the highest concentrations of PCB's in the Housatonic River are present. The rock-and-riffle environment represents a reach of the river channel where active streambed erosion and transport are occurring and where stream velocities do not permit deposition of fine-grained sediment particles that might contain sorbed PCB's. The only time fine-grained sediments carrying sorbed PCB's would move over a rock-and-riffle reach and be potentially available for infiltration is during a high-flow event when the river water is carrying a high suspended-sediment load. During these highflow conditions, however, the velocity of river water should be sufficient to scour material from the streambed along a rock-and-riffle reach as well as to prevent particles from settling. Also, dissolved 
PCB's are not present in river water in concentrations greater than $0.1 \mu \mathrm{g} / \mathrm{L}$. Even if river water containing PCB's were induced to infiltrate an aquifer adjacent to a rock-and-riffle reach, the PCB's would be sorbed to the sediment at the water/sediment interface and removed from the recharge water.

\section{SUMMARY AND CONCLUSIONS}

PCB's have accumulated in the river sediments along the entire length of the Housatonic River in Massachusetts. However, the highest concentrations of PCB's, up to $140,000 \mu \mathrm{g} / \mathrm{kg}$, were found in the bottom sediments of the Housatonic River between Pittsfield and Woods Pond Dam in Lee, Mass. The most significant quantities are present in ponded reaches of the river where fine sediment can accumulate. The largest quantity of PCB's, 11,000 pounds, or about 50 percent of all the PCB's in the entire river system, is stored in the bottom materials of Woods Pond. These PCB-laden bottom sediments in Woods Pond are gradually being buried by new, less contaminated sediments. This encapsulating process should limit the amount of PCB's readily available for transport downstream in the future, although dam failure or flooding may result in resuspension and make the PCB's available for transport. However, at present, about 490 pounds of PCB's move downstream past the gaging station at Great Barrington each year. Furthermore, it seems that dissolved PCB's move downstream in the water, but in concentrations at or below the detection limit of $0.1 \mu \mathrm{g} / \mathrm{L}$ for the analytical method used.

PCB's that are sorbed to the bottom sediments (up to $110,000 \mu \mathrm{g} / \mathrm{kg}$ ) of Woods Pond have not moved into the aquifer adjacent to the pond under the conditions of induced infiltration that have existed at that site since late 1956. Hydraulic-head gradients between the pond and the aquifer, along with water-temperature gradients and oxidation/reduction conditions, indicate that pond water moves into the underlying aquifer by induced infiltration caused by pumping wells. At one location along the shore of Woods Pond, the upper $40 \mathrm{ft}$ of aquifer contains water recharged through the pond's bottom sediments. At this site, analysis of aquifer materials and ground water from auger holes and wells drilled between the pond and a production well and screened at various intervals throughout a vertical section of the aquifer $5 \mathrm{ft}$ from the edge of Woods Pond show no PCB's at the detectable levels of $1.0 \mu \mathrm{g} / \mathrm{kg}$ for aquifer material or $0.1 \mu \mathrm{g} / \mathrm{L}$ for water. These data show that PCB's have not moved from the riverbottom sediments containing high PCB concentrations into the underlying aquifer under induced infil- tration conditions, and can be used to conclude that, because of their strong sorbtion to sediments, PCB's would not be expected to move into an aquifer adjacent to any reach along the river.

\section{REFERENCES}

Cohen, Philip, Franke, O. L., and Foxworthy, B. L., 1968, An atlas of Long Island's water resources: New York State Water Resources Commission Bulletin 62, $117 \mathrm{p}$.

Collins, W. D., 1925, Temperature of water available for industrial use in the United States, in Contributions to the hydrology of the United States, 1923-24: U.S. Geological Survey Water-Supply Paper 520, p. 97-104.

Connecticut Academy of Science and Engineering, 1978, PCB and the Housatonic River - A review and recommendations: Connecticut Academy of Science and Engineering, 24 p., 1 app.

Crump-Wiesner, H. J., Feltz, H. R., and Yates, M. L., 1973, A study of the distribution of polychlorinated biphenyls in the aquatic environment: U.S. Geological Survey Journal of Research, v. 1, no. 5, p. 603-607.

Environmental Criteria and Assessment Office, 1980, Ambient water quality criteria for polychlorinated biphenyls: U.S. Environmental Protection Agency, Office of Water Regulations and Standards, Criteria and Standards Division, EPA-440/5-80-68, 190 p.

Frimpter, M. H., 1973, Ground-water management, south shore coastal streams, Massachusetts, section 3.03: U.S. Geological Survey open-file report, $37 \mathrm{p}$.

Frimpter, M. H., and Gay, F. B., 1979, Chemical quality of ground water on Cape Cod, Massachusetts: U.S. Geological Survey Water-Resources Investigations Report $79-65,11 \mathrm{p}$.

Frink, C. R., Sawhney, B. L., Kulp, K. P., and Fredette, C.G., 1982, Polychlorinated biphenyls in Housatonic River sediments in Massachusetts and Connecticut: determination, distribution, and transport: Connecticut Agricultural Experiment Station Bulletin 800, 20 p., 1 app. of $23 \mathrm{p}$.

Geraghty, J. J., and Miller, D. W., 1965, Investigation of ground-water conditions at Lee, Massachusetts: Geraghty and Miller, Port Washington, N.Y., 14 p., 2 app. of $21 \mathrm{p}$.

Griffin, R. A., and Chian, E. S. K., 1980, Attenuation of water-soluble polychlorinated biphenyls by earth materials: U.S. Environmental Protection Agency, Office of Research and Development, EPA-600/2-80-027, $93 \mathrm{p}$.

Guswa, J. H., and LeBlanc, D. R., 1981, Digital models of ground-water flow in the Cape Cod aquifer system, Massachusetts: U.S. Geological Survey Water Resources Investigations Open-File Report 80-67, 128 p.

Haque, R, and Schmedding, D. W., 1976, Studies on the adsorption of selected polychlorinated biphenyl isomers on several surfaces: Journal of Environmental Science and Health, Bulletin 11, p. 129-137. 
Haque, R., Schmedding, D. W., and Freed, V. H., 1974, Aqueous solubility, adsorption, and vapor behavior of polychlorinated biphenyl Aroclor 1254: Environmental Science and Technology, v. 8, no. 2, p. 139-142.

LeBlanc, D. R., 1982, Sewage plume in a sand and gravel aquifer, Cape Cod, Massachusetts: U.S. Geological Survey Open-File Report 82-274, 35 p.

Mackay, D., and Wolkoff, A. W., 1973, Rate of evaporation of low-solubility contaminants from water bodies to atmosphere: Environmental Science and Technology, v. 7 , no. 7, p. 611-614.

Miller, Stanton, 1983, The PCB imbroglio: Environmental Science and Technology, v. 17, no. 1, January 1983, p. $11 \mathrm{~A}-14 \mathrm{~A}$.

Morrissey, D. J., 1983, Hydrology of the Little Androscoggin River valley aquifer, Oxford County, Maine: U.S. Geological Survey Water-Resources Investigations 834018, $55 \mathrm{p}$.

Motts, W. S., 1972, Ground-water investigation in the Lenox-Lee area: Ward S. Motts, Amherst, Mass., $36 \mathrm{p}$.

Nelson, N., Hammond, P. B., Nisbet, I. C. T., Sarofim, A. F., and Drury, W. H., 1972, Polychlorinated biphenyls: environmental impact: Environmental Research, v. 5, p. 249-362.

Nisbet, I. C. T., and Sarofim, A. F., 1972, Rates and routes of transport of PCBs in the environment: Environmental Health Perspectives, no. 1, p. 21-38.

Norvitch, R. F., Farrell, D. F., Pauszek, F. H., and Peterson, R. G., 1968, Hydrology and water resources of the Housatonic River basin, Massachusetts: U.S. Geological Survey Hydrologic Investigations Atlas HA-281.

Oloffs, P. C., and others, 1973, Factors affecting the behavior of five chlorinated hydrocarbons in the two natural waters and their sediments: Canada, Journal of Fish- eries Research Board, v. 30, p. 1619.

Schoor, W. P., 1975, Problems associated with low-solubility compounds in aquatic toxicity tests: theoretical model and solubility characteristics of Aroclor 1254 in water: Water Research, v. 9, p. 937-944.

Silvey, W. D., and Johnston, H. E., 1977, Preliminary study of sources and processes of enrichment of manganese in water from University of Rhode Island supply wells: U.S. Geological Survey Open-File Report 77-561, 33 p.

Task Committee on Preparation of Sedimentation Manual, Committee on Sedimentation, 1966, Sediment transportation mechanics: initiation of motion: American Society of Civil Engineers, Journal of the Hydraulics Division, v. 92, no. HY2, p. 291-314.

Uhlken, L. D., and others, 1973, Apparent volatility of PCBs as used in continuous flow bioassays: PCB Newsletter, 5, 4 p.

U.S. Department of Commerce, 1969, Climates of the states, Massachusetts: U.S. Department of Commerce, Climatography of the United States no. 60-19, 19 p.

U.S. Geological Survey, 1969, Map of flood-prone areas of the East Lee quadrangle, Massachusetts: U.S. Geological Survey.

Wershaw, R. L., Fishman, M. J., Grabbe, R. R., and Lowe, L. E., eds., 1983, Methods for the determination of organic substances in water and fluvial sediments: U.S. Geological Survey Techniques of Water-Resources Investigations, bk. 5, chap. A3, Open-File Report 82-1004, p. 50-67.

Westin, R. A., 1979, Polychlorinated biphenyls 1929-1979: Final report: U.S. Environmental Protection Agency, Office of Toxic Substances, EPA 560/6-79-004, 22 p., 3 app. of $60 \mathrm{p}$. 
